\title{
SOMOS AS NOSSAS MEMÓRIAS
}

Elisete Schwade

(GCS/PPGAS/DAN/UFRN)

Somos as nossas memórias. Portanto, o resultado, não só daquilo que lembramos, mas especialmente dos processos marcados de interação e interlocução que construímos ao longo de um caminho, indefinido, passado e presente, experiência, vivência e registro.

Textualizo aqui a memória da minha formação e trajetória acadêmica na Universidade Federal do Rio Grande do Norte, texto escrito como parte dos requisitos para a progressão para Professora Titular.

Memórias são sempre seletivas, por definição. A seleção que apresento obedece a certa lógica na construção de uma narrativa que foi se revelando na medida em que eu puxava os fios e buscava entrelaçamentos. Deparei-me com algumas recorrências que fazem sentido a partir de um olhar distanciado, um olhar que vê o passado com imagens e ideias do presente. Assim, na textualização da experiência vivida, emergem os ricos aprendizados, sempre como relato, lembrança e narrativa, pois a experiência, essa está no corpo e em todas as memórias afetivas.

Quando comecei a escrever, eu me dei conta de que esse é meu primeiro exercício de um olhar sobre a minha trajetória, uma vez que essa etapa, a de apresentação do memorial, não constava do concurso público a que me submeti para ingresso na UFRN em 1994. Embora algumas nuanças da minha trajetória se inscrevam na necessidade de mencionar questões difíceis, tais como embates no exercício do poder e o aprofundamento da desigualdade, que tem se acentuado em todos os contextos contemporaneamente em razão do grave momento político que vivemos no Brasil, escrevi este texto com satisfação e prazer, num exercício do desejo de dar continuidade as minhas atividades acadêmicas sempre referenciadas na luta por justiça, na igualdade com respeito à diferença e na dignidade para todas/os.

Uma das referências para refletir sobre minha trajetória é o universo de relações plurais que compõe minha experiência, as interações em diversos contextos que fazem parte desse percurso, a construção da agência, mas também o poder. Se exercitei certa coragem que aprendi desde o universo familiar, na forma como meus pais sempre enfrentaram momentos difíceis, que poderia situar como um aprendizado de agência, não deixei de perceber constantemente a dimensão do poder e as relações de desigualdade.

Começo este texto falando de onde vim. Incorporei no relato do meu processo de formação a infância e a educação básica, devido à necessidade de identificar o lugar da minha fala, tanto no que se refere ao percurso quanto ao modo como estabeleço um diálogo constante com essas lembranças hoje, enquanto atuo em políticas de permanência na universidade. Um autor importante para pensar sobre as conexões entre as origens sociais e a formação escolar é Pierre Bourdieu, na forma como reflete sobre a desigualdade e as relações de 
classe desde os seus primeiros escritos acerca da educação ${ }^{1}$. Na proposta de uma ênfase na prática, valorizando a ação e o sujeito, as argumentações desse autor atentam para a necessidade do rigor de contextualização sociológica, observando o universo relacional no interior de um campo em que estão posicionados os indivíduos. Como assinala Renato Ortiz, referindo-se aos diálogos de Bourdieu com Marx, sobretudo no campo da educação, na leitura de Bourdieu, "as ações sociais são concretamente realizadas pelos indivíduos; mas as chances de efetivá-las são objetivamente estruturadas no interior da sociedade global" (ORTIZ, 1983, p. 10). Daí decorre a argumentação deque as trajetórias educacionais devem ser pensadas a partir da ênfase na noção de um campo em que o capital social/cultural está distribuído de maneira desigual. Se percebo isso nesse olhar sobre a minha trajetória escolar, continuo observando a reprodução desse padrão educacional nos diferentes contextos e nos processos de escolarização e de formação com os quais tenho dialogado: a desigualdade situada como resultado das relações de poder no interior de um determinado campo.

É pela chave fornecida por esse relato da minha trajetória escolar e da formação em Antropologia que construí, no decorrer do texto, uma leitura do meu percurso acadêmico e das atividades na Universidade. Uma das principais marcas da minha trajetória é a realização de atividades de pesquisa, de ensino e de extensão de maneira integrada. Essa associação entre as atividades foi se desenvolvendo por meio de acontecimentos, com rupturas e continuidades. $\mathrm{Na}$ medida em que textualizo esse percurso, percebo o quanto foi possível adensar investimentos em pesquisa por meio da atuação no ensino e na formação em diferentes atividades de extensão.

Toda minha formação se deu em universidades públicas. Tive bolsa da CAPES e, assim que defendi minha dissertação, realizei o concurso para a vaga de Teoria Antropológica na UFRN, a qual ocupo até o presente momento e cuja atuação é objeto de diálogo neste memorial. A continuidade dos estudos de pós-graduação também se deu com afastamento remunerado e bolsa da CAPES, assim como um estágio de pós-doutorado no exterior. Além disso, tive apoio para participar de eventos no exterior e auxílio financeiro em projetos de pesquisa e extensão, conforme relato no decorrer do texto. Faço esse registro no sentido do agradecimento e, sobretudo, como forma de enfatizar minha responsabilidade para continuar na luta por um ensino superior público de qualidade, com acesso democrático e políticas de permanência.

Como palavras-chave, as categorias principais que compõem o registro que apresento são: deslocamentos, movimentos, fronteiras, gênero, militância e subjetividade, com o risco de desconsiderar outras que também foram relevantes. Não só na pesquisa, mas também no ensino e na extensão, incorporei os ensinamentos do fazer antropologia e da prática da etnografia. É o que estarei considerando no registro de aspectos importantes da minha trajetória - leituras, em que interiores emergem nas capitais; em que fronteiras, mais do que espaços de conflito e instabilidade, potencializam os deslocamentos e fazem emergir novos aprendizados.

\section{DE ONDE EU VIM: DOS INTERIORES ÀS CAPITAIS, EDUCAÇÃO E ACESSO À UNIVERSIDADE}

Nasci em uma comunidade camponesa do Sul do Brasil, município de São Lourenço D'Oeste. Sou a quinta filha de um casal de agricultores que, em 1958, migrou do Rio Grande do Sul para o Oeste de Santa Catarina, então 
importante fronteira agrícola ${ }^{2}$. Na mesma comunidade, residiam também alguns familiares, tios e primos, e praticamente todos os nossos vizinhos eram descendentes de alemães e falavam um dialeto em alemão. Foi com ele que eu aprendi a me comunicar com o mundo a minha volta, brincando com primas e outras amigas da redondeza.

Tenho uma lembrança muito nítida da distribuição geográfica dos moradores nessa comunidade, chamada Lageado Antunes. Atravessando a estrada principal, situada como uma espécie de fronteira, residiam os que eram chamados "gringos", descendentes de italianos. Na medida em que fui avançando em meus estudos sobre os processos de ocupação das terras no Oeste catarinense, na minha graduação e principalmente no mestrado, tive uma compreensão mais aproximada dessa lógica. As terras nas comunidades rurais daquelas regiões eram comercializadas pelas chamadas Companhias Colonizadoras $^{3}$, que procuravam, na oferta, organizar a venda e a formação dessas localidades a partir de pertencimentos identitários distintos - étnicos, linguísticos, religiosos, entre outros ${ }^{4}$. Isso me fez entender não apenas a separação alemães/ italianos mas também outras especificidades de pequenas localidades no Oeste catarinense, como, por exemplo, uma concentração de adeptos das religiões protestantes, e compreender os principais sentidos da colonizaçãos.

Residindo entre descendentes de alemães, esse dialeto foi a minha primeira socialização e só tive um contato efetivo com a língua portuguesa quando passei a frequentar a escola, com 05 anos. Tratava-se das chamadas Escolas Isoladas, multisseriadas. Desse modo, estudantes de todos os níveis pertencentes ao que então compunha o Ensino Fundamental I, na época chamado de "primário", estavam em uma mesma sala e eram atendidos pela mesma professora. Permaneci nessa escola até o $4^{\circ}$ Ano.

Além da escola, uma série de pequenas tarefas era de minha responsabilidade, no âmbito da organização cotidiana e familiar. No universo camponês, a socialização se estabelece como parte de um ensinamento prático, em que, precocemente, as crianças são introduzidas em aprendizados, de acordo com a sua idade. Trata-se de uma concepção bastante específica de "trabalho", relacionado ao cuidado próximo a casa, ao auxilio no manejo de pequenos animais, à limpeza do terreiro, entre outros.

Na minha família, "estudar" sempre mereceu ênfase. Meus pais se esforçavam para que meus irmãos permanecessem na escola após o $4^{\circ}$ Ano quando finalizavam o então chamado primário. Assim, meu pai organizou com vizinhos um revezamento e todas as noites buscava os meus irmãos mais velhos para estudar no ciclo seguinte (chamado "ginásio") na sede do município, distante $16 \mathrm{~km}$ - eles iam de ônibus regular no final da tarde e retornavam com os pais nesse revezamento, considerando que a estrada era de barro e o carro, um Jeep, Desse modo, levava-se cerca de uma hora para ida e uma hora para volta.

Essa dificuldade fez com que houvesse um investimento para que os meus irmãos migrassem para cidades próximas a fim de estudar, o que implicava também o ingresso no mercado de trabalho na cidade, definido como "urbano", ainda muito jovens. Uma das estratégias, recorrente nas comunidades camponesas do Sul do Brasil, era o direcionamento para a vida religiosa católica, filhos homens nos seminários e filhas mulheres no convento, que garantia local para estadia e estudo. Além disso, poderia despertar a vocação de moças e rapazes para o sacerdócio ou tornar-se freira, como bem ressaltou Miriam Grossi (1990), em sua pesquisa sobre as freiras, na qual aponta que essa estratégia remetia a diferentes dimensões da organização familiar camponesa. Assim, eu tive uma irmã e um irmão que permaneceram por certo período em convento e seminário, respectivamente. 
Além desses dois irmãos, outra irmã, amais velha, trabalhou como empregada doméstica na casa de uma família "conhecida", repetindo um padrão recorrente de que esse "reconhecimento" constituía-se em um diferencial positivo e fazia desse trabalho um local de "proteção". Meu irmão mais velho trabalhava em um escritório de contabilidade. Nesse período, em 1976, já era possível ir para a escola com transporte coletivo regular - com custo particular. Meus pais eram considerados "colonos fortes", isto é, aqueles que, embora com as limitações das estradas, da falta de energia elétrica e de outros serviços de infraestrutura, dispunham de recursos suficientes para auxiliar na manutenção dos que já estavam nas cidades e também para pagar o deslocamento diário de quem frequentava a escola na sede do município. Assim, cursei um semestre da então $5^{\mathrm{a}}$ série em idas/retornos diários até a sede do município.

Com a mão de obra na roça reduzida, tendo em vista a migração dos filhos para estudar, meus pais decidiram se estabelecer em uma pequena cidade próxima, em julho de 1976, quando eu estava no quinto ano, onde passaram a trabalhar como comerciantes, contando com o auxílio de todos os filhos, inclusive do meu, após o horário de aula. Foi em colégios públicos de duas cidades pequenas do Oeste catarinense onde concluí minha formação até o ensino médio, então segundo grau, sempre continuando essa trajetória de auxílio nas atividades dos meus pais no comércio nos horários em que não estava na escola. Em uma realidade em que, nas escolas, faltavam professores e sobraram lacunas na formação, minha formação no ensino médio foi de técnico em contabilidade, a única opção disponível.

\section{O ACESSO AO ENSINO SUPERIOR E À GRADUAÇÃO, PASSADO E PRESENTE: POLÍTICA, LAÇOS COLETIVOS E SUBJETIVIDADE}

Como mencionei, a formação religiosa católica fez parte da minha socialização. Sempre muito envolvida com o que se chamava "as coisas da igreja", desde a adolescência, eu atuava como catequista e também participava de uma organização denominada Grupo Jovem. Minhas atividades de lazer, tal qual na pequena comunidade rural, seguiam vinculadas ao espaço religioso: participação em reuniões, missas, missões e eventos. Foi nesse processo que tive contato com padres e freiras, bem como com seminaristas e aspirantes, que se reconheciam na chamada Teologia da Libertação ${ }^{7}$, referenciada como ala progressista da igreja católica.

Durante o ano de 1982, quando estava concluindo o ensino médio, na época denominado segundo grau, colegas dos grupos de jovens que estavam no Seminário Diocesano de Chapecó - então liderado pelo Bispo D. José Gomes, reconhecido como uma referência na formação de padres para a ala progressista -, tiveram um papel importante para que eu despertasse um desejo de ruptura com o contexto em que vivia. Num primeiro momento, a perspectiva de sair se traduziu em uma espécie de revolta e rebeldia, o que com frequência se associa ao "ser jovem". Mas a continuidade desse processo foi a busca pela universidade, de difícil acesso, que exigiu a saída da casa de meus pais e a mudança para a capital do estado, Florianópolis, cidade distante mais de $600 \mathrm{~km}$. Um esforço da minha família para pagar aluguel permitiu a realização de um cursinho preparatório concentrado para possibilitar a aprovação no vestibular, uma vez que a escola que frequentei não forneceu base para tal empreendimento. Assim, ao final de 1982, fiz um cursinho intensivo e realizei a prova do vesti- 
bular pleiteando uma vaga no curso de Psicologia na Universidade Federal de Santa Catarina - UFSC.

Sem êxito na minha primeira opção, fui convocada para a segunda, Filosofia. Cursei um semestre de Filosofia na UFSC e, quando me preparava para um novo vestibular, já estava encantada com a disciplina de Sociologia. Lembro até hoje dos textos que me empolgaram nas aulas de Introdução à Sociologia, como, por exemplo, "Tio Patinhas no Centro do Universo" de José de Souza Martins, uma das minhas primeiras aproximações reflexivas sobre "o modo capitalista de pensar" (título do livro, do mesmo autor), entre outros. Nesse sentido, eu me sentia fascinada, sobretudo pelas referências que auxiliavam na percepção de distinções entre mundos, desigualdades de classe, nas relações entre rural e urbano e nas diferenças entre contextos. Foi então que decidi fazer o vestibular para Ciências Sociais.

Esse foi um período de descobertas e desconstruções. Passei a me situar em relação a uma série de eventos recentes que então compunha a conjuntura do Brasil, da qual tinha pouco conhecimento. O país vivia ainda o impacto dos 20 anos de ditadura e começava a luta pelas Diretas Já, um dos primeiros processos de mobilização política em que me engajei efetivamente, participando já a partir da organização no movimento estudantil. Em algumas ocasiões, tinha dificuldade de compreender, tal era a quantidade de informações. Morando em Florianópolis e já na universidade, tive como uma referência fundamental o pertencimento a um grupo composto por jovens católicos que atuavam em diferentes pastorais - pastoral da juventude, pastoral universitária, entre outras. As atividades que envolviam esses grupos me puseram em contato sempre mais frequente com a construção coletiva da militância.

O que garante a permanência no ensino superior nesse contexto de rupturas? Nessa perspectiva, é importante estabelecer um diálogo com minha atuação recente em programas de permanência de estudantes na UFRN, bem como com orientações de alunos que estudam deslocamentos de jovens de origem rural e de comunidades populares no ensino superior ${ }^{8}$. Programas e políticas de permanência têm se situado como fundamentais para o êxito na formação universitária, o que se acentuou no decorrer dos últimos anos, em que políticas de cotas e novos modelos de ingresso nas universidades públicas, tais como o ENEM, têm oportunizado um acesso mais democrático ao ensino superior. Nesse sentido, na UFRN, tivemos programas como Conexões de Saberes, no qual atuo desde 2006 (hoje é um programa PET Conexões de Saberes), que sinalizam resultados importantes no êxito da formação dos estudantes de origem popular. Cabe, portanto, um parêntesis para falar sobre essa ação e sua relevância.

A UFRN, mesmo antes da adoção do ENEM para o ingresso de alunos em seus cursos, mantinha políticas de acesso para estudantes oriundos de escolas públicas, com a aplicação do chamado "argumento de inclusão" no exame vestibular'. O Programa Conexões de Saberes, implementado por meio de um edital do MEC em 2006, teve como objetivo central viabilizar a permanência dos estudantes que entravam na UFRN por meio das políticas que democratizam o acesso. A partir da formação de grupos, com a orientação de professores, os estudantes deveriam realizar atividades de extensão em comunidades cujas características remetessem a suas origens, rurais ou urbanas ${ }^{10}$. Esses grupos eram interdisciplinares, de diferentes cursos e, para realização das atividades em projetos de intervenção, era realizada uma preparação prévia, na qual sempre incorporei as reflexões sobre os significados da extensão universitária a partir da introdução à Antropologia e de uma aproximação com a etnografia. 
Como bem nos ensina Claudia Fonseca (1998), a ênfase na desconstrução, na contextualização, pode ser ferramenta importante no estabelecimento dos diálogos de profissionais da área da educação e da saúde com os diferentes contextos em que atuam. Além disso, esses estudantes tinham um reforço em cursos de produção textual, ministrados por profissionais do Departamento de Letras. O projeto esteve em vigência entre 2006 e 2011, quando foi incorporado como um Programa de Educação Tutorial específico. Atuei nesse programa de 2006 a 2008 e depois de 2009 a 2010. Tivemos vários estudantes que, conforme assinala José Jorge de Carvalho (2015), em referência às ações afirmativas, sinalizaram que o mérito a ser considerado não deve ser restrito ao ingresso nas IES, mas observado também nas possibilidades de desenvolvimento de potencialidades quando esses estudantes já se encontram em seus respectivos cursos. Dito de outro modo, dados de pesquisa apontam que estudantes que ingressam por cotas, sejam raciais, sejam econômicas, têm desempenho acadêmico similar e, às vezes, superior a outros que tiveram uma base de formação sistematizada na educação básica. Daí a importância de políticas de cotas associadas à permanência, sobretudo em um contexto de desigualdades que se reproduzem, como é o caso do Brasil.

Após a transformação no grupo PET, em 2011, continuei participando desse Programa, uma vez que o Conexões de Saberes tem na extensão uma de suas referências fundamentais. Junto com outras colegas do Departamento de Ciências Sociais, orientei atividades em assentamentos rurais. Em fevereiro de 2015, submeti um projeto à seleção para a Tutoria do já então PET Conexões de Saberes Comunidade Campo, na qual fui aprovada e assumi desde então a orientação de uma média de 10 estudantes que atuam em diferentes instituições e comunidades, com ênfase no reconhecimento de realidades rurais.

Em uma mirada que retrocede no tempo e refletindo sobre aspectos de minha trajetória pessoal, o êxito desses programas e sua centralidade na vida dos jovens estudantes hoje me faz perceber que, na época que ingressei na universidade, no início dos anos 1980, as referências coletivas citadas, em pastorais da juventude (PJ) e universitária (PU),em diferentes grupos, incluindo o envolvimento com o movimento estudantil, foram fundamentais para que eu desse continuidade ao curso de Ciências Sociais. Faltava-me um capital cultural/ social importante para os estudos universitários, devido à dificuldade de acesso à informação para entender os processos em curso, dado o contexto em que vivi na infância e na adolescência. Mesmo não preenchendo na totalidade as lacunas, foi fundamental a referência desses grupos da pastoral universitária pastoral da juventude, com colegas que traziam informações sistematizadas, indicavam leituras e me iniciavam em outras linguagens (tais como as artes) e, principalmente, acolhiam-me afetivamente nas minhas dificuldades. Isso foi decisivo para a permanência na universidade e a conclusão do curso de Ciências Sociais.

A memória desse contexto me faz hoje atuar efetivamente em ações que favoreçam a permanência na universidade e argumentar a sua necessidade política. Estudos recentes sobre políticas de cotas, por exemplo, são indicativos da necessidade de pensar o desempenho acadêmico sempre contextualizado e as referências teóricas e metodológicas da Antropologia auxiliam nessa tarefa. $\mathrm{O}$ acompanhamento, de perto e de dentro, da trajetória de estudantes que foram bolsistas do programa Conexões de Saberes fornece elementos para essa reflexão. E ainda, aponta para a necessidade de levar em consideração o contexto sociocultural e a origem dos estudantes em todas as práticas educativas - um ensinamento que não fica restrito ao processo de ensino-aprendizagem na educação básica, mas se mostra relevante em todos os níveis, inclusive na universidade. 
Ainda sobre minha formação universitária de graduação, no ingresso no curso de Ciências Sociais me chamava a atenção livros como o de José de Souza Martins (1980), Expropriação e Violência, entre outros, foram referências importantes. Meu interesse se voltava, sobretudo, para os conflitos no campo. No decorrer do curso, desenvolvi uma inclinação maior pela Antropologia, com as aulas da Profa. Maria José Reis sobre comunidades rurais e movimentos coletivos em reação a grandes projetos como as barragens; de Neusa Bloemer, sobre Metodologia e Etnologia; de Maria Amélia Dicke, sobre família, entre outras.

Concluí o curso de Ciências Sociais - Bacharelado na UFSC em julho de 1987. Durante todo o período da graduação, eu contei com o apoio financeiro dos meus pais para custear a minha estadia em Florianópolis. No entanto, não me sentia confortável, identificava nisso um tipo de dependência e buscava autonomia. Já em 1983, procurei oportunidades de bolsa e assumi uma que equivale ao que hoje temos na UFRN como Apoio Técnico.

Em 1984, eu ingressei formalmente no mercado de trabalho, com carteira assinada, inicialmente em um estabelecimento bancário. Trabalhava de oito a dez horas por dia e cursava disciplinas à noite. Trabalhar no banco me desagradava profundamente e continuava em busca de alternativas. Depois de 10 meses, fiz um acordo com a minha família e me submeti à seleção de monitoria em Sociologia rural, decidi romper o contrato de trabalho, assumir a bolsa e terminar o curso. Mas, ainda no ano de 1984, fiz um concurso público para o Instituto de Previdência do Estado de Santa Catarina-IPESC, sendo convocada, em 1985, como agente administrativo, poucos dias após ter assumido a bolsa de monitoria. $\mathrm{O}$ trabalho no IPESC garantiu uma jornada de 30 horas semanais e, consequentemente, a possibilidade de mais dedicação ao curso universitário.

Na graduação em Ciências Sociais na UFSC, na época, não havia a exigência de elaboração de TCC e, quando concluí o curso, estava bastante desanimada com a falta de perspectivas para ingresso no mercado de trabalho como cientista social. Durante certo tempo, vivenciei uma forte crise, manifestava a intenção de prestar novo vestibular para Comunicação Social ou retomar o projeto de formação em Psicologia. Não obstante, não conseguia abandonar um intenso envolvimento com as Ciências Sociais e, no final de 1988, fiz o processo seletivo para o mestrado em Antropologia Social, também na UFSC. Com isso, passei a receber bolsa da CAPES a partir de junho de 1989 e, nesse momento, interrompi minhas atividades no IPESC.

\section{A FORMAÇÃO EM ANTROPOLOGIA NA PÓS-GRADUAÇÃO: MESTRADO, INICIAÇÃO À PESQUISA}

Minha proposta de pesquisa, apresentada como pré-projeto para o processo seletivo no PPGAS/UFSC, envolveu a luta pela terra levada a efeito pelo grupo indígena Kaingang, no Oeste catarinense. Nesse período, o grupo Kaingang do Toldo Chimbangue estava em pleno processo de reivindicação pela retomada da terra. Minha atenção estava voltada para conteúdos desse conflito, que explicitavam diferentes perspectivas acerca da vida no campo e significados atribuídos a terra. No decorrer do primeiro ano de mestrado, redirecionei meu projeto, a partir do contato com a organização dos primeiros assentamentos resultantes dos investimentos do Movimento de Trabalhadores Rurais Sem Terra-MST, no Oeste do Estado de Santa Catarina ${ }^{11}$. Nessa direção, intrigavam-me as referências religiosas na construção da luta política pela terra. 
Os primeiros exercícios de pesquisa marcaram profundamente minha trajetória acadêmica. Conheci alguns assentamentos no meio-oeste catarinense (como exemplo, no município de Matos Costa) e fui apresentada às dificuldades relacionadas à permanência na terra, num contexto em que várias pesquisas buscavam refletir sobre as possibilidades de êxito das propostas de organização ${ }^{12}$. Nesse processo de reconhecimento das novas configurações, até então ainda muito recentes no meio rural, o assentamento denominado Conquista na Fronteira, situado entre fronteiras estaduais, no município de Dionísio Cerqueira e na divisa entre Santa Catarina e Paraná e, também, limites nacionais, entre Brasil e Argentina, foi apontado como um dos assentamentos "mais organizados". Esse foi o local de minha primeira experiência de pesquisa com orientação antropológica.

Na revisão de literatura, além da importância do Oeste catarinense como cenário de organizações coletivas, despontava também a referência fundamental da igreja progressista para a construção das lutas políticas no MST, sobretudo em virtude da atuação da Comissão Pastoral da Terra, de modo especial com o Bispo D. José Gomes. Desse modo, foi se desenhando meu projeto de dissertação, uma pesquisa sobre o projeto político-religioso de residentes em um assentamento modelo para o MST. Um processo que me iniciou na construção da interlocução antropológica, sobretudo no que se refere ao trabalho de campo.

Desde a definição do projeto, mergulhei profundamente nas questões que envolvem as relações de poder e reposicionam de modo constante os sujeitos no processo de interlocução na pesquisa. Para realizar as etapas de campo, construí uma aproximação lenta, a partir das referências — militantes — que eu tinha em virtude do envolvimento com a igreja católica progressista, com atuação em diferentes pastorais, como já mencionei. Ao chegar ao assentamento, eu me vi diante do enfrentamento de um diálogo com jovens filhos de "colonos" - inclusive, alguns deles oriundos do município em que meus pais residiam, um processo de estranhamento envolto em conflitos em que me sentia constantemente questionada.

A reflexão sobre a pesquisa de campo no Conquista na Fronteira deu origem ao meu primeiro artigo acadêmico, publicado em 1992, em um projeto do NIGS -UFSC, no caderno "Trabalho de Campo e Subjetividade"13. O título do artigo, "Poder do sujeito, poder do objeto: reflexões sobre um processo de pesquisa em um assentamento de trabalhadores rurais", é extremamente revelador do mar de questionamentos em que fui lançada nessa primeira experiência de pesquisa de campo. De imediato, tive a consciência de que, se fazer antropologia era um grande aprendizado sobre $o$ outro, era ainda maior sobre $o$ mesmo, como bem sinaliza o título de um artigo de Miriam Grossi (1992) sobre o tema na mesma coletânea.

O assentamento Conquista na Fronteira é organizado, daquele período até o presente, de maneira a não identificar os lotes individuais, enfatizando um projeto coletivo. "Tudo é coletivo, discutido, votado, incluído no regimento", costumam dizer. Nesse cenário, a organização do trabalho, a gestão do espaço, como o local de construção das casas, de estábulos, bem como benfeitorias e realização do plantio, incluindo os cuidados com a saúde, as diretrizes de projetos na educação e as regras de convivência cotidiana, todas essas ações devem ser rigorosamente seguidas para fazer parte do grupo. Nessa gestão coletiva, as atividades produtivas e de organização do cotidiano se concentram na Cooperativa ${ }^{14}$, com um tipo de administração que envolve uma rotina cotidiana de atenção a questões de ordem burocrática associado a um investimento constante na discussão política. 
No que diz respeito à pesquisa, realizada em 1989-1990, esta teve duas etapas, ambas de três semanas, em que eu ficava hospedada no assentamento ${ }^{15}$. Na primeira etapa, momento de reconhecimento do assentamento, eu circulava o tempo todo entre as casas. Para tanto, a coordenação organizava minha agenda indicando onde deveria dormir e em qual casa faria as refeições ${ }^{16}$. Já na segunda etapa conversei com a organização interna (a coordenação) e solicitei permissão para ficar em apenas uma casa, na condição de uma hóspede ${ }^{17}$. Em outros momentos, também fiz uma espécie de visita, como na ocasião em que fui passar um dia no assentamento acompanhada da minha orientadora, Profa. Miriam Grossi, em 1991. Circular, conhecer todos, conversar com todos, era a regra do assentamento. Essa foi a orientação e era assim que eles recebiam visitantes.

A reflexão sobre essa experiência de campo foi marcada por conflitos, os quais envolveram também questões de ordem subjetiva resultantes do meu diálogo com o projeto político do grupo no contexto e da posição que o MST ocupava naquele momento. No assentamento, era evidente a presença de um grupo de militantes que posteriormente veio a assumir papel de liderança nacional. Nesse sentido, não só temas da gestão cotidiana, tais como possibilidades de permanência na terra, eram pauta da discussão política, mas também, de modo especial, a continuidade da luta pela terra. Assim, desde os primeiros movimentos de construção daquela proposta de ocupação da terra e de gestão das relações cotidianas, evidenciou-se o destaque à militância do grupo e ainda uma referência a um tipo de troca.

Ressalte-se que foi minha relação com militantes da Comissão Pastoral da Terra e com outras organizações coletivas de apoio ao MST que me permitiu a realização da pesquisa ${ }^{18}$. Se por um lado permitiu o acesso, por outro, fazia sentir uma espécie de "culpa" constante, a cada passo que eu dava no trabalho com os dados etnográficos. Nesse processo, uma espécie de militância partilhada gerava dificuldades de distanciamento e exercício da reflexão crítica, implicando um longo processo de amadurecimento. Hoje, lendo o texto de Cristine Chaves (2006), que trata da participação em um evento do MST (a Marcha dos Sem Terra) e dos dilemas relacionados à construção desse movimento como ator político, lembro-me dos inúmeros conflitos em que me vi envolvida nas situações complexas e tensas de relações interpessoais cuja solução mesclava o ativismo político. Na medida em que os meus diálogos com o MST se intensificaram, aprendi a me posicionar em um movimento de distanciamento, sobretudo pela posição institucional, na condição de professora: sempre deixo bem claro que, embora contem com meu apoio e a minha solidariedade, não faço parte do MST.

A militância exigia um tipo especial de dedicação que, naquele momento, no início dos anos 1990, era crucial para a consolidação do MST. No caso do assentamento Conquista na Fronteira, um fator que concorria para uma ênfase ainda maior na dedicação e na militância era a grande quantidade de solteiros, jovens que nos anos seguintes assumiriam importantes cargos no MST. Inclusive, cinco jovens dividiam uma casa, situada em uma posição estratégica, no centro do assentamento, referência de passagem para ter notícias e acesso a diferentes informações.

Naquele momento, o investimento militante se traduzia como dedicação integral, sacrifício, viver a luta, com assembleias, reuniões, participação, agenda intensa, tempo marcado com rigor, horários sempre previamente estabelecidos e cronometrados de trabalho, espaços para o lazer, vidas dedicadas à vivência do projeto coletivo e da luta política. Realizavam-se assembleias semanais para distribuir tarefas e informar sobre diferentes aspectos da construção da cooperativa. Além disso, havia várias reuniões, tanto dos núcleos quanto das diferentes comissões, enfim, constituía-se como uma organização que terminava estabelecendo um contato constante entre os moradores. Como 
espaço de encontro, as reuniões fortaleciam pertencimentos, no mesmo ritmo em que definiam papéis ocupados na construção da proposta do coletivo, visto que, como sublinha John Commerford (2000), as reuniões são espaços que, na medida em que acontecem, informam posições e papéis dos envolvidos e posicionam sujeitos na luta.

Nesse processo intenso - e tenso - de reflexões, surgiu um dos meus primeiros textos acadêmicos, já mencionado, publicado em 1992, que permitiu uma primeira elaboração dos componentes subjetivos nas aproximações e nos distanciamentos em processos de interlocução. A reflexão sobre subjetividade na pesquisa passou a fazer parte da minha trajetória acadêmica, retomada em diferentes momentos, sobretudo na participação das atividades do NIGS ${ }^{19}$. Participei da organização e coordenação de Grupos de Trabalho (GTs) e apresentei trabalhos sobre a subjetividade na pesquisa antropológica em eventos da área, tais como RAM ${ }^{20}, \mathrm{RBA}^{21}$ e ANPOCS ${ }^{22}$, o que ampliou o leque de diálogos e de reflexões sobre essa questão. Desde 2006, esses GTs focalizam também o recorte de gênero e a subjetividade ${ }^{23}$. Também, recentemente, retomei a reflexão em um artigo publicado em livro em homenagem a Gilberto Velho incorporando, assim, novas questões sobre etnografia e subjetividade na pesquisa antropológica ${ }^{24}$.

Diante do exposto, concluir a dissertação de mestrado foi uma tarefa árdua. Eu me vi em um processo de iniciação e desafiada ao exercício de autonomia na pesquisa, imersa em inúmeras situações e envolvimentos subjetivos em campo que exigia posicionamentos, respostas, e tudo o que conseguia era elaborar novas perguntas. Com isso, aprendi muito sobre os significados da luta pela terra, fui situando aos poucos os colonos e as colonas que faziam parte da minha história no Oeste catarinense, ao mesmo tempo que me via envolta na reflexão sobre a familiaridade das referências religiosas em todo o cotidiano.

Lembro que, já nessa época, houve referência à "mística" 25 no MST, assunto que fez parte de um diálogo que tive com uma das lideranças do assentamento em que realizei a pesquisa. Perguntei o que significava a mística e ele respondeu: "Para nós, o grito de uma palavra de ordem substitui a reza". Fui compreendendo então a importância da prática religiosa da Teologia da Libertação para a construção política da luta, não apenas pela constante presença dos setores progressistas da igreja (padres, freiras e dirigentes pastorais) mas sobretudo pela referência simbólica ao sagrado em todos os momentos de construção da militância, às vezes remetendo a componentes messiânicos (como na referência a um dos mitos de origem do MST, que relaciona o surgimento do movimento às lutas do contestado); noutras, trazendo o enfretamento do sofrimento, a solidariedade e a partilha comunitária que atualizava valores morais incluindo a dimensão política ${ }^{26}$. Desse modo, fui desenvolvendo uma reflexão sobre a luta, não como parte da vida, mas como a própria vida.

Defendi minha dissertação em 1993 e só pude compreender o que significou esse processo muitos anos depois. Vale destacar alguns desses aprendizados: a percepção sobre o componente religioso e a sua importância na luta pela terra, na viabilização do assentamento; e o projeto militante, que se estendeu a interlocuções mais recentes que mantenho com o mesmo grupo. Ademais, o investimento de pesquisa focada no resgate de trajetórias de mulheres militantes, objeto em projetos recentes, fez perceber que o pertencimento à igreja católica e as referências religiosas seguiram sendo fundamentais, inclusive como possibilidade de ampliar a luta e realizar contatos internacionais ${ }^{27}$.

Em outra direção, o estudo do projeto político-religioso dos residentes no assentamento conquista na fronteira foi um marco significativo de muitas fronteiras e rupturas que hoje, nesse olhar sobre o passado, com imagens e 
ideias do presente, percebo como parte da minha trajetória acadêmica. Isso me fez mergulhar nos dilemas e nos conflitos que fazem parte de processos que, como no caso da luta pela terra, implica lidar com contextos de indefinições e longos períodos de liminaridade. Nesse sentido, meu investimento na reflexão sobre a relação com a chamada igreja progressista e a Teologia da Libertação fez pensar na construção desse cotidiano, em um movimento de aproximação e distanciamento - minha origem camponesa - , na relação que desenvolvi com as pastorais e a militância, na condição de mulher pesquisadora. Por conseguinte, foram se delineando reflexões que permearam todos os processos de pesquisa e interlocuções que desenvolvi no decorrer de minha trajetória acadêmica, sobretudo nos recortes de ênfase na subjetividade e no gênero, em deslocamentos, e fronteiras.

\section{"ANTROPOLOGIA DA MULHER": “QUESTÕES DE GÊNERO”, PODER E SUBJETIVIDADE}

No período do mestrado, também tive contato com a literatura antropológica sobre questões feministas e "questões de gênero". Cursei a disciplina Antropologia da mulher, ministrada pela Profa. Miriam Grossi. A ênfase desse curso estava direcionada, sobretudo, ao questionamento de identidades definidas pelo sexo biológico e pela afirmação da construção social da identidade de homem e de mulher. Para tanto, lemos Simone de Beauvoir, Margareth Mead, Françoise Heritier, entre outras autoras e autores. Lemos ainda uma bibliografia que enfatizava a relação da discussão sobre a mulher com as organizações feministas e coletivas em movimentos sociais. Foi também um momento importante para ampliar a reflexão sobre subjetividade e desconstrução de identidades essencializadas, bem como percepções sobre o universo relacional do poder, possibilidades e limites da construção da igualdade, questões que envolveram teoria e prática no curso: a disciplina começou coma presença de alguns homens que acabaram desistindo e isso foi objeto de reflexão constante.

Essa disciplina, no mestrado, somou-se a outras referências teóricas e metodológicas importantes para a minha formação e meu investimento em pesquisa. Um curso ministrado pela Profa. Luzinete Minela, tópico teórico especial sobre "Poder e subjetividade", no qual discutimos principalmente Max Weber, Michel Foucault e Félix Guatari, foi fundamental para aprofundar referências teóricas que remetem à construção/desconstrução e ao processo de produção de reconhecimento identitário e subjetivo. Ademais, a disciplina de Teoria Antropológica Contemporânea, com o Prof. Rafael Menezes Bastos, foi marco fundamental que possibilitou um contato com uma bibliografia que então se tornava mais acessível e que teve grande impacto na reflexão sobre a pesquisa antropológica, as referências e as obras situadas como "discussões pós-modernas" ${ }^{28}$.

A pesquisa do mestrado se situou também como desencadeadora de um modo de refletir sobre realidades, tais como a dos assentamentos rurais, buscando uma compreensão a partir da complexidade ${ }^{29}$. A atenção para o "diálogo" desses grupos com contextos diferenciados, quais sejam: a noção de heterogeneidade (origens distintas dos assentados e militantes); os reflexos no cotidiano; o desafio da proposta de coletivização; a organização da produção e seus impactos nas relações familiares; a participação política, limites e possibilidades na "construção da igualdade" em se tratando de gênero e geração, conforme já mencionei, estimularam-me a pensar no contexto da construção 
de um projeto político influenciado pela religiosidade e me fizeram perceber a multiplicidade e a heterogeneidade de pertencimentos.

Hoje vejo, em outros investimentos de pesquisa, que aquela experiência constituía-se em uma maneira de olhar para essas realidades, levando em consideração questões que iam além da sua localização como "campesinato", "contextos rurais", agricultura, "luta pela terra". No desafio de realizar uma etnografia do grupo residente no assentamento Conquista na Fronteira, procurei enfatizar o cotidiano do grupo, as relações familiares, a divisão do trabalho, as práticas de socialização e educação. Mas foi necessário contextualizar essa reflexão no pertencimento ao MST, pois a dinâmica do assentamento me reportava para a construção desse movimento diariamente imerso em conflitos, dissensos, e, apesar disso, gerava muita vontade de lutar e solidariedade. Este foi um ensinamento fundamental da pesquisa antropológica, de que totalidades são sempre construídas com a participação efetiva de quem se aventura ao seu registro - no caso, eu, na minha iniciação na condição de pesquisadora.

\section{NOVOS DESLOCAMENTOS: OESTE DE SANTA CATARINA, NORDESTE DO BRASIL E OUTROS CAMPOS}

O interstício entre a conclusão do mestrado, dissertação defendida em julho de 1993, e o ingresso no doutorado, em março de 1996, envolveu deslocamentos de diferentes ordens que apenas menciono e vou retomar como objeto de reflexão mais adiante, quando me referir ao ensino de Antropologia. Já em 1991, ingressei como docente de Antropologia ${ }^{30}$ em uma universidade no Oeste de SC, o que implicou a mudança de cidade, de Florianópolis para Chapecó- SC.

Após concluir o mestrado, eu me submeti a concurso público na Universidade Federal do Rio Grande do Norte, um novo deslocamento, dessa vez para uma realidade geográfica e culturalmente mais distante. Por conseguinte, passei a residir em Natal-RN, após a aprovação para uma vaga na disciplina Teoria Antropológica. Eu não conhecia o Nordeste e tinha pouca experiência em viagens. No mesmo período, foram realizados concursos para várias áreas, outros colegas de SC também participaram, alguns foram aprovados, como a minha colega Lisabete Coradini e Ana Laudelina F. Gomes.

No processo em que me estabelecia na UFRN, fiz algumas leituras de Antropologia urbana e tive contato com referências que, em 1995, emergiam como um conjunto de práticas que afirmava uma "nova era". Na perspectiva de dar continuidade ao investimento nas questões de gênero, elaborei um projeto de pesquisa sobre o feminino no universo neo-esotérico, o qual submeti ao PPGAS $^{31}$ da USP no final de 1995. Assim, no início de 1996, ainda vivendo os impactos e a instabilidade da migração da região Sul para o Nordeste, surgiu uma nova mudança de cidade, dessa vez para São Paulo. Esse investimento precoce no doutorado (tendo como referência o ingresso recente como docente na UFRN) foi uma decisão que levou em consideração a necessidade de investimento imediato na qualificação, dado o incentivo do PICDT, programa de qualificação de docentes da CAPES, que em 1995, durante o governo de Fernando Henrique Cardoso, estava sob ameaça em razão dos cortes pelo enxugamento da máquina pública. Para tanto, contei com bolsa CAPES e afastamento com remuneração para curso de doutorado.

No primeiro ano de doutorado, vivi essa nova fronteira com intensidade. Morar em São Paulo, cidade difícil, lançou-me num mar de questionamentos e desafios - por que tantos deslocamentos recentes? Ao mesmo tempo 
estava bastante entusiasmada em estudar na USP, uma instituição importante na formação de linhagens de antropólogos e da pesquisa na antropologia brasileira.

O ano de1996 foi marcante também por outro acontecimento, destes que a vida nos presenteia: engravidei do meu primeiro filho, Daniel, e me vi diante do desafio e da beleza da maternidade. No processo em que assumia a partilha da minha vida, e das idas e vindas, com Savio Araújo, Daniel nasceu em maio de 1997, quando já havia retornado para Natal onde tinha definido que realizaria o trabalho de campo. O nascimento de Daniel transformou a minha relação com a vida, ensinando-me diariamente.

\section{NA ANTROPOLOGIA URBANA}

No primeiro ano do curso de doutorado, cumpri créditos e construí uma aproximação com as pesquisas e os pesquisadores do Núcleo de Antropologia Urbana - NAU, coordenado pelo meu orientador, Prof. José G. Magnani, além de cursar a disciplina Antropologia Urbana. Tive oportunidade também de cursar Teoria Antropológica Contemporânea, com o Prof. Roberto Cardoso de Oliveira, que naquele semestre (1996.2) encerrava a sua participação como professor visitante na USP. Durante esse ano, vivi intensamente as atividades da USP. Destaque para um evento mensal, chamado sexta do mês, em que tive oportunidade de assistir a palestras sobre diversos temas, com importantes antropólogos de instituições brasileiras e internacionais.

O desenvolvimento de meu projeto de tese se constituiu numa nova fronteira em minha trajetória no âmbito da pesquisa, desde que resultou no desenvolvimento de um tema que estabelecia alguns contrastes com a minha experiência anterior. Refletindo sobre essa escolha como parte da memória, percebo que foi de extrema importância o desenvolvimento desse trabalho nas referências da antropologia urbana, com a possibilidade de me aprofundar em outra literatura, etnografias sobre sociabilidades, heterogeneidade, apropriação de espaço, lazer e circulação nas cidades, vida urbana, estilos de vida, segmentos médios, outro olhar sobre a vida e o mundo.

Quando concluí o mestrado, estava bastante interessada em dar continuidade à discussão das questões de gênero. Temas relacionados, como família, violência contra a mulher, eram objeto de discussão nas disciplinas que eu ministrava na UNOESC ${ }^{32}$, sobretudo no curso de Serviço Social. Já no meu primeiro ano na UFRN, no primeiro semestre de1995, organizei um evento e um minicurso sobre a temática, curso esse ministrado pela Profa. Miriam Grossi e que reuniu várias organizações feministas, além de intensificar o contato com a Profa. Elizabeth Nasser, antropóloga e feminista.

No projeto que desenvolvi no doutorado, a princípio, eu percebia certas linhas de continuidade com minha experiência de pesquisa anterior, a exemplo também da dimensão da religiosidade, que me fez atentar para a importância das chamadas práticas esotéricas na vida cotidiana dos adeptos. Não obstante, de imediato, foram se apresentando novas rupturas - o questionamento necessário sobre as práticas e os conteúdos, que já não apresentavam aspectos que as permitisse pensar como religiosidade per se. Lembro que fiz um longo investimento na revisão de literatura sobre religiosidade, que se mostrou com pouco rendimento e indicou a necessidade de um deslocamento para outras contextualizações dessas práticas, vinculadas a estilos de vida urbanos que atualizavam referências múltiplas e heterogêneas, tais como artes divinatórias, práticas terapêuticas tradicionais, estilos idiossincráticos de vivências espirituais, a relação com o consumo, entre outros. Como se tratava de um tema 
emergente, fiz uma revisão de literatura que percorreu artigos em periódicos acadêmicos, textos publicados em anais de eventos, espaços que tinham como particularidade o fato de não estarem restritos a temas ou a áreas de conhecimento - ou seja, encontrei referências em eventos sobre religiosidade, saúde, antropologia urbana, entre outros. Esse mapeamento por si só se constituiu em uma experiência importante, o que me fez retomar essas referências após a defesa da tese em um artigo que submeti e foi publicado na BIB/ANPOCS ${ }^{33}$.

No desafio de compreender um universo ainda pouco pesquisado (sobretudo no recorte do feminino), que se apresentava como difuso, com contornos pouco definidos, situo outro aprendizado na pesquisa antropológica realizada no doutorado: etnografar processos em construção. Hoje diria com segurança que a etnografia é sempre construção e processo. A elaboração da tese de doutorado permitiu reforçar essa noção, na realização de uma etnografia de experiências, encontros e espaços neoesotéricos no Nordeste, tendo como referência a centralidade do feminino. Nesse sentido, busquei registrar distintas manifestações das chamadas práticas neoesotéricas, nos modos de organizações de eventos e nas diferentes ações e, em especial, no movimento de atrizes, atores e agentes. Isso fez compreender que as referências difusas associadas à nova era, vistas a partir do feminino ${ }^{34} \mathrm{e}$ o registro da centralidade que assumiam na vida de mulheres, compunham um tipo particular da organização da vida dos adeptos. A pesquisa, realizada em três cidades diferentes, em Recife/PE, Campina Grande/PB e Natal/RN, registrou um circuito $^{35}$ importante de difusão dessas práticas no Nordeste do Brasil.

Finalizei o doutorado em 2001 e minha inclinação pela continuidade da pesquisa sobre as práticas neoesotéricas vinha perdendo força, tal qual esse movimento que estava em um processo de inflexão após virada do milênio. Não obstante, o rico aprendizado e o registro de um processo em construção me reportaram novamente a um dos campos de pesquisa em Campina Grande onde, com um olhar então mais distanciado, percebi um aspecto significativo dessas práticas, a saber: a capacidade que seus adeptos tinham de percebê-las em diferentes eventos significativos das experiências vividas, da associação com o momento do nascimento até a morte. A partir desse registro, retomei um dos pontos que desenvolvi na tese e escrevi um artigo que sugeriu essa tendência, publicado na revista "Religião e Sociedade" ${ }^{36}$.

\section{OUTROS MOVIMENTOS, NOVAS FRONTEIRAS: GÊNERO E GERAÇÃO, CONTEXTOS RURAIS E URBANOS}

Após a conclusão de doutorado, na expectativa de ampliar a pesquisa em contextos urbanos, elaborei um projeto sobre gravidez na adolescência voltado para a abordagem dessa questão em segmentos populares. O tema buscava também dar continuidade às reflexões sobre gênero, com enfoque no universo relacional do masculino e feminino, situado no contexto das relações de juventude, responsabilidade e paternidade. Esse foi o meu primeiro projeto registrado na $\mathrm{PROPESQ}^{37} / \mathrm{UFRN}$, no qual tive a participação de uma bolsista de iniciação científica.

Estava ainda no início dessa pesquisa quando, em 2002, fui convidada para ministrar um curso de Antropologia no curso de graduação Pedagogia da $\mathrm{Terra}^{38}$, cuja turma era composta por militantes do MST e residentes em assentamentos rurais. Tratava-se de um curso modular ${ }^{39}$, com aulas intensivas, sempre com uma disciplina durante uma semana. Essa etapa do curso aconteceu em 
um campus da UFRN situado em uma cidade no interior do RN - Nova Cruz. O espaço estava em reforma e foi adaptado como local para as aulas e também funcionava como alojamento, meu e dos cerca de 60 alunos. Tudo era muito precário, um prédio que estava sem água encanada e sem instalações adequadas, o que me fez lembrar de processos de acampamento e início da organização de assentamentos, a experiência do mestrado.

As minhas lembranças eram acionadas sobretudo pela organização rígida do cotidiano daqueles estudantes, com uma agenda diária a ser cumprida que iniciava com o entoar do hino do MST, o hasteamento da bandeira, a celebração da "mística", enfim, um dia após o outro assim, ritualizado, orquestrado pela disciplina militante. Nessa perspectiva, havia leituras escolhidas e indicadas por dirigentes do MST que deviam ser feitas pelos estudantes e tinham horários determinados. Tratava-se de um espaço que aliava a formação universitária ao projeto de formação de militantes. Palavras de ordem eram lembradas e proferidas coletivamente a todo o momento, no decorrer das aulas, nos intervalos, nos horários das refeições, sempre em referência à luta pela terra.

Estavam presentes também tensões resultantes de tal empreendimento que alia a formação em Pedagogia à militância política. Nesse sentido, da mesma maneira que Cristine Chavez (2006) relata que reencontrou tensões dos acampamentos na marcha pela terra, ministrar essa disciplina no curso Pedagogia da Terra foi uma espécie de retorno a uma organização exemplar proposta pelo MST e que tinha causado profundo impacto na minha subjetividade no processo de pesquisa do mestrado. Similaridades que indicam o modo pelo qual o MST procura manter acesa a luta política, produzindo um modo especial de ativismo, que inclui as referências do estudo, do enaltecimento constante da luta, da disciplina cotidiana. Ademais, cursos tais como o Pedagogia da Terra, reivindicados pelo MST e viabilizados com a participação dessa organização política, indicam também transformações nas intencionalidades desse importante movimento social, com uma ampliação do seu campo de atuação, estabelecendo fortes ações em políticas para a educação. Tais experiências, que envolvem também outras áreas disciplinares, como História, Serviço Social, entre outras, indicam uma preocupação com formações que aliem o acesso ao conhecimento de áreas específicas com a luta política, que facilitam o ingresso no ensino superior, sobretudo para mulheres e jovens.

A experiência desse curso me impactou profundamente. Ministrei a disciplina de Introdução à Antropologia de forma intensiva, optando pelo formato oficina em alguns momentos como escolha metodológica de melhor rendimento. Entre os temas que deveria focalizar, de acordo com a ementa, estavam as relações rural/urbano, gênero e religiosidade. Quando introduzi a reflexão sobre religiosidade, solicitei que, organizados em grupos, os participantes listassem práticas religiosas com as quais tinham contato ou que conheciam. No decorrer da atividade, soubemos que, naquela turma, participavam duas mulheres que se definiam como "rezadeiras", o que era de total desconhecimento dos colegas, que na ocasião já estavam no segundo módulo. Também observava as condições das mulheres que participavam do curso, com as quais estabeleci um diálogo constante. Algumas estavam acompanhadas de seus filhos menores, que realizavam atividades na "ciranda" ${ }^{40}$.

Portanto, ensinar Antropologia para esse grupo me fez refletir sobre os sentidos da luta pela terra, agora ampliada, envolvendo também processos formativos. Isso me despertou para a continuidade do investimento em pesquisa com as populações residentes em assentamentos rurais no Nordeste. Essa nova etapa de pesquisa já "nascia" sob forte impacto de um olhar a partir das referências da literatura das chamadas sociedades complexas/antropologia urbana, o que se evidenciava no meu interesse nos trânsitos dos participantes 
desses projetos de formação entre diferentes contextos. Percebia, por exemplo, a importância que aquela formação nos cursos PRONERA tinha para as populações residentes nos assentamentos, sobretudo os jovens e as mulheres. No decorrer desse processo, o que se pôde ver, contudo, era a dificuldade da continuidade na luta após a conclusão dos cursos tais como o de Pedagogia da Terra, conforme observei na continuidade de pesquisas sobre trajetórias de jovens residentes em assentamento no Sul e no Nordeste do Brasil. Nesse caso, ou eles tendiam a romper com os projetos coletivos do assentamento para trilhar caminhos que contemplam projetos individuais após a formação, ou estabelecem rupturas parciais e remodelam padrões de participação nas atividades coletivas, como é o caso dos alunos formados em cursos como Pedagogia da Terra no RN, que realizaram concursos públicos e ministram aulas em escolas fora dos assentamentos, mas retornavam em períodos intercalados e nos finais de semana. Isso aponta para diferentes padrões de assimilação e continuidade do projeto da militância por parte dos jovens, em uma intensificação de relações entre contextos rurais e urbanos. Retomo essa questão adiante.

Acompanhei todo o processo do curso Pedagogia da Terra até 2006, quando aconteceu a formatura da turma, em um grande ritual, já no espaço Patativa do Assaré, em Ceará Mirim/ $\mathrm{RN}^{41}$. Orientei trabalhos de conclusão de curso que versavam sobre gênero, militância e juventude. Foram intensos os processos de discussão que me incentivaram na continuidade da pesquisa sobre militância e a curiosidade sobre a especificidade da realidade de assentamentos rurais em outras regiões, nesse caso, no Nordeste do Brasil.

No decorrer do curso, foram se evidenciando também importantes conexões de diferentes realidades, viabilizadas pela expansão do MST e pelos deslocamentos por meio da militância. O uso de livros tidos como referenciais sinalizavam que muitos integrantes da igreja progressista, com os quais tive contato na pesquisa realizada em SC, tinham se tornado autores de textos importantes, atuando como intelectuais orgânicos do MST. Também tive contato com militantes agora residentes no RN que vieram do Sul do Brasil, com a tarefa de "organizar o movimento" no Nordeste. Nos anos 1990, houve um grande movimento de militantes que vieram do Sul para Norte/Nordeste ${ }^{42}$. Fui percebendo então aspectos importantes na ampliação da luta pela terra e na consolidação do MST, bem como um processo que diferencia pelo envolvimento no ativismo e discussão política.

Os militantes que vieram do Sul, com frequência, relatavam conflitos. Os significados desses deslocamentos, conforme sugere Débora Franco Lerrer (2008), apontam para um padrão de migração intrínseco ao modo como o MST se expandiu nacionalmente, uma chave explicativa para a cultura política (LERRER, 2008, p. 20-21). As experiências partilhadas, conforme também pude verificar na minha pesquisa, envolvem as origens da organização, com fortes vínculos com o projeto político-religioso da igreja católica (SCHWADE, 1993); mas tem também desdobramentos importantes nas trocas e partilhas de referências culturais.

Retomei a pesquisa no local, em um assentamento situado no município de Touros, no RN, chamado Aracati. Tal enfoque nos sujeitos inseridos nas realidades de assentamentos do $\mathrm{RN}$ trouxe contribuições significativas para refletir sobre a militância, contextualizada nas inovações que a realidade dos assentamentos imprimiu no mundo rural. Permitiu observar também nuanças relacionadas ao diálogo com processos históricos específicos, que singularizam identificações com o trabalho na terra. Assim, se na luta pela terra no Sul do Brasil os filhos de colonos eram o grupo predominante, no Nordeste, em virtude de outras configurações no processo histórico de ocupações de terras, predominam 
assentados que viviam na condição de morador, sitiante, entre outros vínculos com a terra (SIGAUD, 2006).

Na pesquisa em Aracati-RN, focalizei inicialmente as questões relacionadas à geração e ao gênero, inspirada no projeto sobre paternidades em grupos periféricos urbanos, percebendo assim a possibilidade de novos planos comparativos. Nesse grupo, alguns residentes têm uma longa história de participação política na luta pela terra e na organização sindical da região. Trata-se de um assentamento que, não obstante seja pioneiro na região, apresenta ainda grandes dificuldades na consolidação do projeto, com uma sequência de tentativas de organização da produção na terra e projetos coletivos, ainda pouco exitosos.

No caso dos jovens residentes em Aracati-RN, um dado que chamou minha atenção foi a procura constante de trabalho fora do assentamento, associado ou não à expectativa da migração do campo para a cidade. A busca por oportunidades de concurso público também aparecia de maneira recorrente. Observei que as mulheres jovens também participavam ativamente desse processo, ou seja, seguiam o mesmo padrão migratório dos jovens homens. Tal fato me fez considerar os diferentes padrões de relacionamento conjugal (SCHWADE, 2010), reveladores de importantes questões no que se refere às permanências e às transformações nos papéis e nas referências ao gênero e à geração na realidade de assentamentos na região. Se, por um lado, a iniciativa das jovens mulheres que buscavam trabalho fora do assentamento em sintonia com o projeto de seus companheiros parecia revelar certa agência, por outro lado, encontrei situações de mulheres jovens que viviam relações que poderíamos chamar de "conservadoras" - totalmente atreladas às vidas dos companheiros. Além disso, observei que essa relação mais equilibrada nos papéis de gênero esbarrava nos limites que o contexto empunha para ambos, como, por exemplo, as limitações para ingresso no mercado de trabalho, que atingia jovens mulheres e homens.

Além da pesquisa, minhas reflexões seguiam também em referência ao acompanhamento do curso Pedagogia da Terra e, posteriormente, Magistério da Terra (esse último no nível do ensino médio). Todas essas atividades, educativas e de formação política, aconteciam no centro de formação mencionado, chamado Patativa do Assaré e gestado pelo MST no Rio Grande do Norte.

Esse envolvimento resultou também em outras solicitações, dentro das práticas de atividades de extensão na UFRN, como cursos de formação em cooperação para grupos e associações nos assentamentos. Em um desses cursos, organizei, junto com a Profa. Irene Paiva, do Departamento de Ciências Sociais, oficinas em educação e cidadania que englobaram a temática da juventude e de gênero. Esse projeto foi interessante por ter implicado atividades em assentamentos rurais distintos, no Rio Grande do Norte, o que me fez conhecer diversas experiências. Além disso, no decorrer desse projeto de extensão, tive contato com uma importante interlocutora, cuja origem remetia a uma pequena cidade no interior de Santa Catarina, a cidade de meus pais, que migrou para o Nordeste como militante para organizar atividades do MST, na década de 1990. Foi um encontro muito significativo para refletir sobre trajetórias militantes. Essa interlocutora se tornou liderança na luta pela terra e na organização de assentamentos e, mesmo tendo rompido com o MST, continuou realizando atividades na região em que reside como assentada (chamada Mato Grande). Na ocasião em que fizemos essa assessoria em cidadania, educação e gênero, as principais atividades foram realizadas no assentamento em que reside, onde, com sua visão empreendedora que permitiu acesso a financiamento, construiu um centro de formação e realizou outras benfeitorias importantes. 
A observação desses contextos e percursos foi evidenciando uma série de interpelações a que os padrões de participação de homens e mulheres estão sujeitos nas realidades dos assentamentos, uma vez que toda organização, busca de financiamentos e participação em projetos exige um percentual de participação das mulheres. Isso me fez investir na discussão de gênero e de geração no processo de construção da militância na expansão da área de atuação MST.

Foi nesse contexto que se deu a decisão de uma nova etapa de pesquisa no assentamento Conquista na Fronteira, em SC, com o objetivo de localizar as questões relacionadas à militância vis-à-vis ao gênero e à geração em distintos contextos - temporais e territoriais - a fim de ampliar as possibilidades da comparação como elucidação mútua ${ }^{43}$. Em 2008, numa breve visita ao Conquista na Fronteira ${ }^{44}$, pude perceber importantes mudanças no processo de consolidação da organização coletiva, sobretudo no que se referia à cooperativa de produção. Soube também, nessa ocasião, que das 60 famílias inicialmente residentes, 35 ainda permaneciam, o que me pareceu um número bastante significativo, tendo em vista a rigidez cotidiana que compunha a proposta do coletivo, que se pauta na continuidade da militância. Mas esse breve contato também trouxe outro dado extremamente relevante, qual seja: o papel de projetos tais como o desse assentamento na globalização do MST.

Nessa breve visita, ouvi falar sobre muitos residentes no Conquista na Fronteira que se deslocavam com frequência para outros países, sempre como parte dos contatos estabelecidos via MST. Também fiquei impressionada com o êxito do projeto de cooperação agrícola, proposta que vi nascer na etapa de pesquisa realizada em 1990-91. Ademais, lideranças que conheci jovens (da "casa dos solteiros", mencionada anteriormente) estavam na presidência de uma cooperativa que aglutinava a produção de uma grande quantidade de assentamentos no Oeste e no extremo Oeste catarinense. No assentamento, todas as casas em que residiam haviam sido renovadas, agora com alvenaria, instalações sanitárias de qualidade e muito conforto. Um frigorífico com selo S.I.F indicava o empenho em projetos de grande alcance. Nesse caso, estava visível, sobretudo, certa estabilidade, visto que uma infraestrutura garantia qualidade de vida e de trabalho para todos os residentes. Fronteiras conquistadas.

\section{DO LOCAL AO GLOBAL, DIÁLOGOS E TRÂNSITOS}

O caráter globalizado de ações coletivas, tais como o MST, vai se evidenciando nas suas articulações com as realidades locais. Assim, utilizando como referência a discussão da etnografia multissituada (multi-sited), sobretudo na abordagem efetuada por Marcus (1996), Robben (2007) e Hannerz (2007), com enfoque na comparação em diferentes dimensões, conexões entre locais, processos e trajetórias, passei a registrar aproximações e distanciamentos entre essas diferentes realidades. Tendo em vista o contato com a realidade de jovens e mulheres em assentamentos, no curso Pedagogia da Terra e no Assentamento Aracati no RN, um retorno ao Conquista na Fronteira SC, com o intuito de focalizar militância, gênero e geração, a organização de aspectos dessas diferentes interlocuções se constituiu num empreendimento importante para refletir sobre questões de ordem mais geral acerca da realidade dos assentamentos e da continuidade da luta pela terra. Estava bastante impressionada com o alcance que o MST teve no Brasil, o que se refletia nesses diferentes contextos: contatos transnacionais, as mediações nos espaços formativos (cursos PRONERA), os processos de diferenciação no local. 
A elaboração do projeto para essa nova etapa de pesquisa se deu durante o período de pós-doutorado na Universty of Brithish Columbia, UBC, em Vancouver - Canadá, entre 2008-2009. A realização do pós-doutorado em uma instituição estrangeira foi um marco importante na minha trajetória acadêmica. A dificuldade com línguas estrangeiras constituiu-se como um dos obstáculos frequentes do meu perfil acadêmico. Residir em um país como o Canadá, que se define como multicultural, e na Cidade de Vancouver, onde $40 \%$ da população é composta de migrantes asiáticos, foi um modo bastante interessante de aperfeiçoar meu conhecimento na língua inglesa, em um contexto no qual me sentia muito compreendida, o que facilitou o aprendizado. Como esse foi um projeto familiar, o processo para acomodar um filho na escola e outro na creche foi um rico aprendizado sobre as condições das mulheres e a educação, no Canadá, na British Columbia, e mais particularmente em Vancouver.

No projeto de pós-doutorado, constava o investimento na reflexão sobre deslocamentos, gênero e geração. Durante a estadia na UBC, tive oportunidade de aprofundar leituras e também frequentei um curso sobre gênero em contextos transnacionais, ministrado pela minha supervisora, Profa. Alexia Bloch. Discutimos processos migratórios e deslocamentos em diferentes contextos, tais como nas relações de trabalho ${ }^{45}$ e na construção de vínculos amorosos. Daí emergiram as indagações sobre os diálogos de especificidades nas relações de gênero, dada a ênfase dessa dimensão já percebida nos assentamentos, com lutas feministas e de mulheres em contextos mais amplos. Passei a me indagar sobre esses trânsitos e deslocamentos no sentido de observar as relações da reivindicação de participação mais efetiva de mulheres e os diálogos com organizações feministas. As mulheres residentes em assentamentos rurais estavam envolvidas em intenso processo de organização para além das fronteiras do MST (MMC ${ }^{46}, \mathrm{MMTR}^{47}$, entre outros) ${ }^{48}$. Assim, elaborei um projeto que foi aprovado numa das iniciativas mais importantes no financiamento da pesquisa sobre questões de gênero no Brasil, a saber: a parceria $\mathrm{SPM}^{49}$ e $\mathrm{CNPq}$, que durou apenas duas edições e rendeu valiosas pesquisas de norte a sul do país.

Como desenvolvimento desse projeto financiado pelo CNPq/SPM, em setembro de 2011, fui ao assentamento Conquista na Fronteira, em Santa Catarina, com o propósito de atualizar os dados sobre a gestão cotidiana e realizar entrevistas com jovens e mulheres. Estava acompanhada de dois estudantes ${ }^{50}$. Dessa vez, nós nos hospedamos em um hotel na cidade de D. Cerqueira e todos os dias viajávamos $30 \mathrm{~km}$ de manhã para retornar à noite. Outras diferenças ficaram evidentes entre a primeira e a segunda etapa de pesquisa no que se refere à posição em campo e às possibilidades de interlocução. A posição de gênero como pesquisadora não ficou tão evidente, o que tem uma relação com o fato de que o projeto do coletivo, agora consolidado, normatiza a presença de mulheres em todos os espaços. Isso faz perceber que a pesquisa se constrói nesse universo de relações dinâmicas, com mudanças nas posições e na constante relação dos assentados com a cidade e a região.

No decorrer dos dez dias de idas e vindas, do assentamento para a cidade, foi possível vero quanto a relação dos residentes no assentamento com a "cidade" havia mudado. Um assentado foi eleito vereador por vários mandatos seguidos, desde 1996, e naquele momento assumia um cargo de secretário municipal. Além disso, percebi uma relação intensa com locais para além do assentamento, que passa pela ida diária de jovens para estudar em escolas de nível médio da região ou em instituições de nível superior em D. Cerqueira-SC.

Na sequência da pesquisa, aos poucos, fui reconhecendo os jovens que, na etapa anterior, em 1989-1990, eram crianças que frequentavam a escola do assentamento, multisseriada e que atende até o ensino fundamental I. De imediato, lembrei de uma indagação constante daquelas crianças que, na época 
da pesquisa, perguntavam se algum dia eu "iria para uma ocupação". Essa pergunta tem o efeito de contextualizar as expectativas que os pais, à época muito jovens, tinham em relação aos filhos. Ao mesmo tempo, contrasta com a dificuldade atual de adesão dos jovens à continuidade do projeto militante.

As relações do Conquista na Fronteira com contextos externos apontam outra dimensão importante: em se tratando de um assentamento que desenvolve um projeto exemplar de organização, sendo esta fundamentada na cooperação agrícola e no coletivo, emergiram várias lideranças que assumiram posição de dirigentes do MST e de organizações correlatas que atuam na luta pela conquista e pela permanência na terra, tais como projetos de cooperação. Nesse sentido, evidenciou-se outro movimento importante de deslocamentos, que contribui para colocar o assentamento Conquista na Fronteira numa posição de reconhecimento, trata-se das viagens constantes, nacionais e internacionais, realizadas pelos militantes e que, além de estabelecer contatos e de se inserir no processo de globalização do MST, imprimem singularidades na experiência subjetiva dos sujeitos protagonistas da expansão do MST.

Lembrei, então, de um momento registrado no meu diário de campo, efetuado na pesquisa realizada em 1989. Uma militante, durante uma assembleia do grupo, leu uma carta de outro militante, também cadastrado como residente, que estava em Cuba para um processo de formação política. Cuba era, em 1990, uma referência importante, dada a inspiração para o modelo de coletivo e de cooperação gestado no assentamento. Soube, alguns anos depois, que a mesma militante que leu tal carta viajou para Cuba. Em 2011, agora com o interesse voltado para a construção da militância e a dimensão do gênero, realizei uma longa entrevista com a mesma interlocutora, reveladora das dimensões que assume o diálogo com realidades externas na consolidação do projeto militante. A trajetória dessa atual importante dirigente nacional do MST e responsável pela construção de relações com outras organizações coletivas traz também elementos importantes para pensar significativas alterações nos padrões de gênero, gestadas na experiência subjetiva da militância. A esse respeito, ênfase especial deve ser dada para os deslocamentos intrínsecos ao projeto militante, os quais se manifestam nas dimensões geográficas, culturais, identitárias.

As relações estabelecidas nessa nova etapa de pesquisa, seguida de mais alguns dias de permanência no assentamento em 2013, bem como os contrastes que permitem, auxiliam na reflexão acerca dos sentidos da militância e dos deslocamentos do gênero e da geração em diferentes situações de ativismos no MST. Destaquei também, nessa nova etapa de pesquisa, a abertura constante que faz com que o espaço e o grupo do interior de D. Cerqueira se situem em fronteiras conquistadas. Conflitos e reveses de uma vida e da organização, que são processos permanentes - nesse sentido, o acesso à terra é somente um ponto de partida —, fazem com que a instabilidade característica das fronteiras seja motor permanente para novos desafios. Além disso, o recorrente investimento em deslocamentos internacionais alia a continuidade do projeto militante com a formação política, bem como com processos educacionais (por exemplo, a partir das trajetórias de interlocutoras/es: permanência em diferentes países para realizar formação; representação do MST em agências de financiamento religiosas internacionais; participação de projetos humanitários no Haiti, entre outros $)^{51}$.

Assim, no processo de pesquisa em que busquei estabelecer diferentes planos comparativos de realidades de assentamento, gênero e militância, desenvolvi reflexões sobre condições de homens e mulheres mas também sobre geração, tendo em vista diálogos das realidades dos residentes dos assentamentos com diferentes organizações - além do MST, Organizações Não Gover- 
namentais (ONGs), organizações políticas, movimentos sociais organizados, organizações feministas e de mulheres, instituições públicas, entre outras.

Desse modo, a pesquisa se estendeu para diferentes contextos de diálogos envolvidos no processo de construção da militância e do ativismo. A etnografia constituiu-se em atividades como os cursos PRONERA, bem como eventos que envolvem organizações feministas e de mulheres, onde as representantes do MST se fazem presentes. Além das atividades do PRONERA no Nordeste, também conheci o processo do curso "Arte no Campo", realizado pelo Departamento de Artes Cênicas da Universidade para o Desenvolvimento de Santa Catarina-UDESC. Estive em um dos módulos desse curso, em 2014, o qual acontecia em um centro de formação de um assentamento em Abelardo Luz (SC). Essas e a outras atividades me permitiram ampliar a compreensão dessa relação educação e formação política, um espaço de conexões viabilizadas pela atuação do MST. Ainda no sentido de mapear essa relação, realizei pesquisa em outros espaços formativos, como no Congresso do Movimento de Mulheres Camponesas em Brasília (2013), no Encontro Internacional da Marcha Mundial de Mulheres em São Paulo (2013) e, em 2014, um registro etnográfico no IV Congresso Nacional do MST, também em Brasília, onde a referência às jovens e mulheres teve um destaque particular ${ }^{52}$.

Uma questão recorrente nas minhas reflexões foi a percepção do processo de luta como aprendizado constante. No MST, alia-se a formação escolar à formação política, nos já mencionados cursos PRONERA. Para os jovens, o estudo passou a ter valor fundamental. Conforme ressaltado em artigo publicado sobre esse processo ${ }^{53}$, o investimento que o movimento faz para o recrutamento dos jovens se deve à expectativa que se tem em relação ao potencial político da juventude (CASTRO, 2005) ou, como diz Regina Novaes, a juventude se caracteriza como um período de autoafirmação e de construção de projetos para que, no futuro, possa reivindicar seu espaço, projetando diferentes modos de vida (NOVAES, 2010). É nesse sentido que uma narrativa de um jovem militante, durante o IV Congresso do MST, em fevereiro de 2014, chamava a atenção para o entendimento do assentamento como espaço do se fazer política. Em diferentes contextos, jovens dos assentamentos da região Nordeste passam a ter oportunidade de escolarização a partir dos engajamentos no MST, ou tiveram algum tipo de contato com o movimento social. Embora ser militante do movimento não fosse requisito para o ingresso, uma vez que os cursos foram abertos a todos que vivessem em áreas de reforma agrária, o engajamento funciona como dispositivo facilitador que garante a entrada.

A preocupação de parte dos jovens de frequentar a escola e conseguir um diploma pode fazer uma grande diferença em suas vidas. Ao analisar a trajetória dos jovens, percebe-se que parte significativa deles revela em seus discursos certa indefinição quanto aos seus projetos de futuro, expressa na tensão entre ficar ou sair do assentamento. Para eles, a oportunidade de ir à escola, de concluir o ensino médio e superior surge como o passaporte para concretizar um projeto diferenciado. Tal projeto pode envolver um investimento em trajetórias nas cidades ou, o que ocorre com frequência, a possibilidade de uma melhoria na condição de vida aliada à continuidade na luta política.

É nesse contexto que o investimento do MST nos jovens tem na educação a sua centralidade. Trata-se de uma estratégia que contempla tanto a luta pelas escolas nos assentamentos como a escolarização associada à formação de militantes. A formação em cursos técnicos e universitários, voltada sobretudo para a juventude, dá suporte à viabilização do projeto político do MST. Além disso, permite o contato dos jovens com diferentes realidades e o diálogo com estilos de vida urbanos, traz também novas necessidades para os assentamentos. Os jovens que permanecem nos assentamentos, de modo geral, assumem ativi- 
dades fora, como professores ou mesmo nas práticas formativas e de organização do MST. São ainda os processos de escolarização, formação e construção do engajamento que oportunizam viagens para outros regiões e países, resultando num processo de formação diferenciado, em que a profissionalização é também o fazer político.

De modo similar, nos assentamentos rurais, tem continuidade a reivindicação de espaço para uma participação mais efetiva das mulheres nas atividades econômicas e na construção do ativismo político, em relações sociais que se estabelecem nas diferentes dimensões no cotidiano. É possível perceber interpelações significativas no que se refere ao gênero e à geração, tanto em situações que envolvem a organização política quanto na inserção em atividades econômicas e produtivas dos assentamentos rurais. Esses posicionamentos, por sua vez, refletem-se nas organizações familiares, nos afetos e em diferentes aspectos da construção subjetiva. Trata-se de um contexto que favorece uma atuação mais efetiva das mulheres, com reflexos na construção da equidade, que fica evidente quando a participação é construída nas experiências cotidianas.

$\mathrm{Na}$ abordagem dos movimentos sociais ${ }^{54}$, observa-se, nas últimas décadas, a intensificação das referências no que diz respeito à presença e à atuação das mulheres, bem como das assim chamadas questões de gênero. Tal presença vem sendo problematizada de diferentes formas, nas quais se sobressai a ênfase em novas dimensões da ação política, como, por exemplo, as chamadas "questões do privado", sublinhadas em virtude da "presença das mulheres"

No MST, argumenta-se a construção da igualdade em torno da categoria novo: "novo homem", "nova mulher", "nova sociedade" como parte do projeto político do movimento. Como ocorre com outros movimentos sociais, o MST, como organização, situa-se em um processo de produção de práticas, no decorrer do qual se moldam comportamentos, desafiam-se tradições, criam-se significados. Tudo isso delineia o que se assume como "transformação da sociedade". Nesse processo, evidenciam-se ações dos sujeitos que têm participação ativa na construção das referências do ativismo. Daí a importância de levar em consideração as trajetórias, as quais apontam os efeitos dos processos de produção de significados culturais e políticos em que as práticas do MST estão inseridas, explicitando dinâmicas nas relações de homens e mulheres e na definição dos papéis masculinos e femininos. No entanto, a incorporação das referências associadas aos diferentes feminismos, suas principais bandeiras de lutas, ainda encontra resistências que são identificadas em todas as instâncias de ação do MST, desde a coordenação até a organização cotidiana dos assentamentos.

No que diz respeito às referências cotidianas, de modo particular nos assentamentos, espaço para uma reflexão mais efetiva sobre as relações de poder, observa-se nas participações de homens e mulheres em atividades do cotidiano doméstico e do espaço de trabalho rural interpelações políticas a partir do gênero. As questões de gênero nos contextos dos assentamentos têm o efeito de produzir indagações sobre as situações vivenciadas pelas mulheres. Também impacta a participação delas em diferentes instâncias de produção e decisórias, bem como nas relações entre homens e mulheres, uma vez que os homens também precisam responder à inclusão da chamada questão de gênero. Isso é percebido pela demanda que recebem das agências financiadoras sobre indicadores da participação das mulheres em projetos coletivos, por exemplo ${ }^{56}$. A título de exemplo, presenciei, no assentamento Aracati no RN, mútuas acusações no que diz respeito a projetos coletivos e à necessidade de contemplar um percentual de mulheres. Em Dionísio Cerqueira, projeto de assentamento onde a organização coletiva é exemplar, as chamadas questões de gênero aparecem com frequência quando se menciona a participação política, mas são destacadas como algo "a ser discutido". 
Com o intuito de compreender esses processos e estabelecer diálogo com tão complexas realidades, retomei referências ao conceito de cultura, sobretudo quando se articulam processos, situações de contato, fluxos. Trata-se de pensar em uma matéria chave da antropologia, qual seja: a tensão entre a questão da generalização versus diversidade, assim como questões presentes nos desdobramentos da categoria gênero. Nesse sentido, recupero algumas contribuições importantes para refletir sobre esses processos.

Como assinala Verena Stolke (2004, p. 78), falando sobre a "cultura de gênero", “...la energía creativa de la antropología emana de la tensión entre dos tipos de exigencias: por un lado nos ocupamos de seres humanos universales y, por otro, de realidades culturales particulares". Tal entendimento, como parte da reflexão antropológica em geral e da incorporação do gênero em particular, assume outras dimensões quando pensado à luz de transformações recentes, fazendo emergir novas questões, de modo especial, em processos tais como a globalização, uma vez que a análise de gênero é fundamental para entender esses novos contextos e o papel da cultura nas experiências cotidianas (LAMPHERE et al., 1997, p. 3; THAYER, 2001).

Nesse sentido, faz-se necessário refletir o que vem sendo considerado como "cultura". A esse respeito, Sherry Ortner $(2006,2007)$ propõe mudanças no uso desse conceito, argumentando a necessidade de utilizá-lo em narrativas mais críticas e políticas. Isso significa uma possibilidade de fugir da homogeneização, do essencialismo e da imutabilidade. Cultura, diz a autora, deve ser entendida não como algo que está aprisionado como interiorização e definição de identidades, mas como portadora de uma natureza pública, com a qual diferentes grupos se relacionam de maneira diversa, uma apreciação crítica do conceito, que alimenta a visão de uma relação mais frouxa entre a cultura e a vida das pessoas ${ }^{57}$.

Essa reflexão sobre cultura está expressa também na diferenciação entre "culture" e "the cultural" (RABINOW; MARCUS, 2008). Seria uma caracterização que envolve críticas ao modo aprisionado por meio do qual a ideia de cultura marca grupos com fronteiras definidas, cujos contornos podem ser delimitados, contrastado com o que se define como "the cultural", entendido como dimensão da vida humana, um plano aberto, em que podemos situar o emergente, o constitutivo e as múltiplas possibilidades de significação. Como sintetiza Rabinow, "the cultural" proporciona uma abordagem e acesso ao objeto de análise de modo mais adequado do que a ideia de "culture", porque "culture", de algum modo, supõe algo que está submetido a um todo ${ }^{58}$.

Assim, na continuidade de minhas pesquisas, interessa-me a noção de cultura relacionada à ação do sujeito no mundo, mais do que cultura como submissão ao todo, pois essa ação do sujeito no mundo se manifesta, entre outros aspectos, na sua participação política, nas referências de gênero, nas suas dinâmicas culturais. $\mathrm{O}$ recorte de minhas pesquisas considera a realidade dos assentamentos rurais sempre em diálogo e entre contextos.

\section{ENTRE CONTEXTOS RURAIS E URBANOS}

O enfoque nas experiências cotidianas, em que busco trabalhar com gênero e geração, fez perceber que os assentamentos são mais do que uma expressão que se acrescenta às inúmeras expressões de "ruralidades" (definidas, por exemplo, em contextos de globalização). Se nas análises de cunho sociológico as questões associadas ao mundo rural contemporâneo remetem de modo frequente a novas ruralidades, à pluriatividade, evidenciadas em modos 
próprios de organização da produção, ainda que mantendo vínculo definidor do rural, tais como a utilização de recursos naturais, notadamente a terra, essas mesmas análises pontuam inúmeros aspectos que indicam a complexificação das relações presentes nessas novas realidades, sobretudo no que se refere à construção identitária.

Na continuidade da pesquisa ${ }^{59}$, desenvolvi uma abordagem dos distintos significados projetados no desenvolvimento de relações que mesclam a permanência nos assentamentos rurais com práticas efetivadas nas cidades como forma de ampliar a compreensão das realidades dos assentamentos no contexto de novos processos de diferenciação. Tal diversidade é parte constituinte do processo de efetivação dos assentamentos, visto que os beneficiados pelos projetos têm origens sociais distintas, envolvendo não apenas trabalhadores na terra, mas também residentes em periferias urbanas. Nesse sentido, é importante identificar de que modo tais origens dinamizam as expectativas relacionadas ao acesso a terra, bem como as interrelações com equipamentos e espaços urbanos. Nessa nova etapa de pesquisa, continuei o exercício de comparação entre duas realidades de assentamentos com configurações distintas e que, por consequência, diversifica as relações com os espaços urbanos e as imagens da cidade.

Estudos recentes sobre o meio rural têm indicado uma diversidade de situações de mulheres em contextos rurais, tendo em vista a dimensão plural da vida no campo. Observa-se um rompimento de associações rígidas com espaços, papéis e atividades, fortemente vinculadas ao universo que se refere como pequena produção, agricultura familiar, em que, de modo frequente, aparece a dicotomia casa/roçado, definindo espaços e atividades para homens e mulheres. Abordagens antropológicas sinalizam um quadro complexo de relações em que se evidenciam articulações entre atividades (pluriatividade), diferenciações em situações de migrações sazonais, intensificação de contatos com espaços urbanos, participação política e militância, entre outros ${ }^{60}$.

Assim, na continuidade de minha pesquisa, vejo que a realidade dos assentamentos rurais evidencia um fluxo de relações sociais que gera comportamentos que desafiam limites entre rural/urbano e, por consequência, impacta de modo significativo nos modos de vida associados a esses contextos, o que fica bastante visível em relação ao gênero e à geração. Embora isso possa ser percebido em diferentes contextos, em tempos de globalização cultural, no caso dos assentamentos, essa relação assume um caráter singular, uma vez que está inserida em um processo de produção cultural que envolve sujeitos com trajetórias diferenciadas, no entanto, reconhecidos coletivamente como assentados rurais.

O estudo de trajetórias de mulheres militantes, suas relações com os diferentes movimentos e instituições, bem como trânsitos que vão do local ao global têm revelado aspectos importantes no que se refere às interpelações acerca do gênero no contexto do ativismo político de luta pela terra (SCHWADE, 2013, 2014). Destaca-se, nas trajetórias dessas mulheres, a manutenção dos vínculos com o trabalho na terra e a viabilização dos projetos de assentamentos, notadamente nas práticas relacionadas ao cultivo e à organização econômica e política. Essa permanência traz indagações visto que diferencia as possibilidades de papéis que as mulheres assumem, como, por exemplo, a coordenação de práticas ativistas que as projetam fora do coletivo do assentamento e também as lideranças em atividades econômicas realizadas nos projetos de assentamentos, ao mesmo tempo que a permanência do vínculo é que dá sustentabilidade e sentido a essa nova posição assumida pelas mulheres.

Em outra direção, pode-se verificar o desempenho de várias funções, muito além daquelas comumente associadas à vida das mulheres no trabalho no 
campo, tais como cuidado da casa e dos filhos e ajuda no cultivo, ou, no caso dos projetos coletivos, "participação na produção". São mulheres que coordenam reuniões, assumem cargos públicos e tarefas diferenciadas, a coordenação de projetos coletivos ou a produção específica - como é o caso da produção de peixe em assentamentos do Rio Grande do Norte. Para essas mulheres, militantes, a cidade é também um espaço onde exercitam práticas que acionam o capital social acumulado no aprendizado da militância. Movimentam-se com facilidade, ao mesmo tempo que usufruem de maneira diferenciada de bens de consumo.

Em outros contextos/assentamentos, de modo especial naqueles próximos às cidades, observa-se também uma grande ocorrência de situações vivenciadas por mulheres residentes em assentamentos rurais que exercem atividades remuneradas nos centros urbanos. Para elas, muitas vezes também para seus companheiros, o acesso à terra significou um lugar seguro para a sua família, com moradia e certa infraestrutura. Assim, buscam na cidade a possibilidade de incrementar a renda, trabalham como diaristas, empregadas domésticas, entre outras atividades. Essas também se inserem no contexto do consumo, nesse caso, voltado para a aquisição de utensílios domésticos, cuidados estéticos, entre outros. Há ainda outras relações com as cidades, como a venda de produtos nas feiras-livres ou para acesso à educação formal.

Portanto, pode-se observar que assentamentos rurais desafiam limites rígidos para dicotomias, tais como: rural/urbano, tradicional/moderno, entre outros. Daí a sintonia de uma reflexão sobre as dinâmicas culturais, em fluxos, processos. Tal ausência de clareza de fronteiras está relacionada com aquilo que a efetivação dos assentamentos significa para os residentes, a saber: experiências particulares decorrentes de um longo processo de participação, como o envolvimento na conquista da terra ou o acesso à terra via diferentes instâncias. Os sujeitos trazem na sua bagagem experiências distintas, tanto relacionadas à diversidade da luta quanto anteriores, devido a inserções diferentes no mercado de trabalho ou na condição de trabalhadores agrícolas. Destaca-se, ainda, a participação do MST na gestão dos assentamentos; a presença de agentes do INCRA e outras instituições; ou a referência à necessidade de projetos para acesso a crédito. Nesse processo, as vivências que se projetam nos diálogos com diferentes realidades dinamizam gênero e geração, conforme foi possível observar em pesquisa realizada no Assentamento Vale do Lírio, cujos dados estão em fase final de análise ${ }^{61}$.

\section{FAZER ANTROPOLOGIA, ENSINAR ANTROPOLOGIA, DA ORGANIZAÇÃO COLETIVA DA PESQUISA E DA RELAÇÃO COM AS ATIVIDADES DE EXTENSÃO E PRÁTICAS EDUCATIVAS}

Da trajetória de pesquisa apresentada, somada à recorrência da relação que sempre estabeleci entre ensino, pesquisa e extensão, resulta a ênfase mais recente de meus investimentos em pesquisa, voltados para a relação entre antropologia, gênero e educação. Atualmente desenvolvo um projeto de pesquisa que estabelece planos comparativos entre diferentes contextos e práticas educativas, dos espaços escolarizados e de formação, na educação formal e movimentos sociais (sobretudo o MST), com o objetivo de perceber os limites e possibilidades na incorporação das referências a gênero e sexualidade ${ }^{62}$. 
O desenvolvimento de minhas pesquisas sobre gênero sempre envolveu o trabalho em grupo e as referências coletivas. Inicialmente, vieram as reflexões no mestrado, no NIGS. Ademais, no retorno ao doutorado, em 2002, com a participação de minhas orientandas de mestrado em Ciências Sociais, junto com outras colegas de curso, organizamos um grupo de estudos sobre gênero e sexualidade, com leituras e discussão de textos e socialização permanente das pesquisas que estávamos realizando. Durante um período, estive vinculada ao grupo de pesquisa CIRS, que então se chamava Cultura, Ideologia e Ciências Sociais. Em 2006, em parceria com Carlos G. O. do Valle, criamos o Grupo de Pesquisa Gênero, Corpo e Sexualidade-GCS, que passou a ser referência no desenvolvimento de pesquisas em gênero e sexualidade na UFRN. O GCS é, também, um importante espaço de discussão entre estudantes de diferentes níveis de formação, com membros de graduação, mestrado e doutorado. Em 2010, Rozeli Porto se integrou ao GCS como docente e, mais recentemente, Angela Facundo e Paulo Victor Leite Lopes. No GCS, além das pesquisas individuais de docentes e discentes, procuramos desenvolver atividades coletivas, projetos e eventos de extensão.

As atividades em projetos de intervenção, de caráter coletivo por definição, fizeram parte do meu percurso acadêmico na UFRN. A partir de 2004, muitas dessas atividades se institucionalizaram e passaram a receber financiamento, dada a ênfase em políticas e programas governamentais que reforçaram a relação ensino-pesquisa-extensão.

Nas minhas atividades de extensão, procurei incluir as reflexões teóricas e metodológicas e temas que compõem minha trajetória de pesquisa. Nesse sentido, por exemplo, no programa Conexões de Saberes e, mais recentemente, na Tutoria do PET, sempre busquei desenvolver atividades em assentamentos rurais com ênfase em gênero (e também em geração, desde que muitas das atividades desenvolvidas envolvem a juventude).

Em outra direção, os projetos de extensão, na temática de gênero, relacionam-se com práticas educativas e ensino, possibilitando outro campo de pesquisa, que venho desenvolvendo em projetos mais recentes. Não obstante, destaco, por exemplo, as temáticas das práticas educativas do MST que permite relacionar educação com a militância e as organizações coletivas em movimentos sociais. Esses movimentos vêm recebendo ênfase nas minhas investidas em pesquisa ora em processo.

Minhas interlocuções em orientações, de graduação, especialização, mestrado e doutorado, envolveram temas diversos, mas articulados de diferentes modos a minha trajetória temática de pesquisas. Concluí 02 orientações de tese de doutorado, 13 orientações de dissertações de mestrado, 05 monografias de especialização e 28 monografias de graduação. ${ }^{63}$ Além disso, há orientações em andamento, a saber: 04 de mestrado, 02 de doutorado e 01 de iniciação científica.

Dos temas presentes nas minhas orientações, destaco a questão de gênero e violência, família, prostituição, construção cultural do corpo nas práticas de body modification, jovens em contextos escolares, masculinidades e vaquejadas. Nesse percurso, há diferentes diálogos com as realidades de assentamentos, tais como: a organização de atividades produtivas "sem veneno" e a participação das mulheres nas atividades cotidianas. A primeira dissertação de mestrado concluída, de Analba Brazão Teixeira, "Nunca você sem mim", sobre homicidas-suicidas, marcou o desafio de tratar de modo recorrente temas e questões que envolvem diálogos com movimentos feministas, tais como a questão da violência contra a mulher, retomando, por outra via, temas da militância. 
No momento, estou orientando 04 dissertações de mestrado, 02 de doutorado. Nas dissertações de mestrado, vem a retomada de temas como: MST, os assentamentos como territórios e juventude rural em contextos de escolarização universitárias, maternidade em segmentos médios. Nas orientações de doutorado, os temas são: gênero, jovens feministas em contextos escolares e prostituição.

Em relação ao ensino, conforme mencionei, defendi minha dissertação de mestrado em julho de 1993 e, antes de mesmo de tê-la concluído, desde 1991, comecei a ministrar aulas de Antropologia na Universidade do Oeste de Santa Catarina - UNOESC. Ensinar antropologia sempre se situou como um desafio. Como ensinar antropologia?

Durante três anos, na UNOESC, em Chapecó, ministrei disciplinas de Introdução à Antropologia para cursos como Pedagogia, Serviço Social, História, entre outros. Essa experiência foi muito significativa, sob vários aspectos. De um lado, desenvolvi a paixão pela docência, ao mesmo tempo que me coloquei diante do desafio de refletir sobre uma realidade familiar, uma vez que essa primeira experiência teve lugar em uma universidade situada na região em que nasci, exigindo distanciamento e um novo deslocamento — identitário, geográfico, cultural. De outro, a experiência acumulada na UNOESC me permitiu uma preparação para o investimento em concursos. No início de 1994, soube de um concurso na UFRN. Eu não conhecia o Nordeste, mas me senti motivada a fazer e, aprovada, em junho de 1994, ingressei como docente na UFRN.

Naquele contexto, os antropólogos da UFRN estavam lotados no Departamento de Ciências Sociais, organizados em uma "equipe de Antropologia". Nessa equipe, fazia-se referência constante ao curso de mestrado que, iniciado como curso de pós-graduação em Antropologia em 1979, foi, em seguida, em 1982, transformado em mestrado em Ciências Sociais. Os primeiros semestres foram de reconhecimento acerca das relações entre diferentes áreas articuladas como Ciências Sociais, agora na experiência da formação do corpo docente. Aprendi aos poucos sobre os quadros complexos que compuseram relações entre profissionais de Antropologia, Ciências Sociais e Ciências Humanas.

Foi nesse contexto que se delineou, em 1998, a motivação para a criação do Departamento de Antropologia, um desejo já cultivado por vários professores, alguns naquela época em processo de aposentadoria, como Nassaro e Elizabeth Nasser. Ainda ativos, entre os mais antigos, Anita Queiroz Monteiro, Terezinha Martins e Luiz Assunção. A esses, somaram-se outros que estavam chegando mais ou menos na mesma época que eu (que nesse período já me encontrava afastada para doutorado): Lisabete Coradini, Luciana Chianca, Julie Cavignac, Francisca Miller e Eliane Tania Freitas. Foi com esse grupo que, em 1999, participei da criação do Departamento de Antropologia. Esse foi um passo importante no sentido de dar visibilidade à produção em Antropologia na UFRN. A autonomia na organização administrativa favoreceu o pleito por vagas e a realização de concursos e abriu possibilidades de reestruturação da Antropologia nessa instituição. Assim, foram chegando outros professores, como Carlos Guilherme Valle, Edmundo Pereira, Rozeli Porto, Juliana Melo, Rita Neves, Glebson Vieira e, mais recentemente, Angela Facundo e Paulo Vitor Leite Lopes.

Em 2001 e 2002, respectivamente, o Departamento ofereceu cursos de pós-graduação nível especialização em Antropologia. Naquele período, os cursos de especialização em Ciências Sociais e, particularmente, Antropologia, eram pouco oferecidos nas universidades brasileiras ${ }^{64}$. No Departamento de Antropologia, podemos situá-los como um processo preparatório para a criação do Programa de Pós-Graduação em Antropologia Social, nível mestrado, 
aprovado pela CAPES em 2004 e do qual fui a primeira Coordenadora. Vale ressaltar que, na época de criação do PPGAS/UFRN, eu e outros professores do Departamento de Antropologia-DAN já integrávamos o corpo docente do Programa de Pós-Graduação em Ciências Sociais, onde permaneci até 2010.

Em 2005, tivemos o ingresso da primeira turma de mestrado. Esse processo marcou também o fortalecimento das relações institucionais com a Associação Brasileira de Antropologia-ABA. Retomo esse aspecto adiante.

Também em 2005, simultaneamente à abertura oficial do PPGAS/ UFRN, mais precisamente no início de maio - um dia cabalístico, 05.05.2005 —, nasceu meu segundo filho, José Ivo, mais um presente e inspiração, que engrandeceu todas as minhas ações, minha trajetória pessoal e profissional.

Sobre meu envolvimento com o ensino de antropologia, é importante ressaltar a atuação em outras frentes. Não só o ensino, mas também a reflexão sobre educação se constituem como uma das referências importantes da minha trajetória acadêmica, conforme já mencionei. Nos percursos acadêmicos, entrelaçam-se afetos e amizades e, nesse processo, mantive estreito contato com um grupo de pesquisa do então Departamento de Educação, GEPEM-Grupo de Estudos e Práticas Educativas em Movimento, coordenado pela professora Marta Pernambuco, do qual participa também outra interlocutora fundamental na minha vida profissional e pessoal, minha amiga e comadre Irene Paiva, com quem aprendi e continuo aprendendo muito. Também foi nos contatos do GEPEM que conheci meu cônjuge Sávio Araújo, companheiro indispensável, com quem partilho as dores e as delícias da vida desde 1995.

A partir dos contatos com o GEPEM, desenvolvi alguns projetos nesse grupo, a saber: um projeto financiado pelo CNPq e também as primeiras participações em cursos PRONERA, já mencionados. No diálogo com os profissionais da Educação, tive oportunidade de ampliar minhas reflexões sobre práticas educativas, exercitando propostas dialógicas e também refletindo sobre contextos educacionais. Ministrei curso de Antropologia no Programa Pró-Básica, uma das primeiras tentativas de universalizar a formação universitária para professores da educação básica, projeto que foi desenvolvido pela UFRN em 2002.

Outra experiência importante no ensino de antropologia foi a proposta de interiorização associada à Educação a Distância-EAD. Nessa perspectiva, coordenei duas edições do curso de aperfeiçoamento Gênero e Diversidade na Escola, entre 2010-2011 e depois 2013-2014. Essa atuação me aproximou ainda mais da realidade da educação básica no Rio Grande do Norte. A partir desse exercício, elaborei projetos para o edital PROEX, em 2013 e 2014, com a perspectiva de "Semear Gênero na Educação". Iniciativas nesse sentido se mantiveram contínuas até o presente, envolvendo o grupo de pesquisa GCS.

Ainda no âmbito do ensino, devo destacar a participação nos cursos do GEEMPA ${ }^{65}$. Desde 2012, faço parte de um grupo de antropólogas/os que se integra aos propósitos de práticas educativas chamadas pós-construtivistas. O que ensinamos: Introdução à Antropologia e também o uso de algumas ferramentas na nossa área para educadores. No GEEMPA, o pressuposto de que as práticas educativas devem ser sempre contextualizadas recebe uma ênfase à parte. Trata-se de um dos aspectos principais da proposta, ou seja, o educador deve reconhecer o contexto sociocultural do educando, o que, conforme indica um significativo acúmulo de experiências, é visto como condição para o êxito da alfabetização.

Ampliando essa proposta, percebemos que a nós, professores de Antropologia, caberia conhecer os profissionais que estavam em formação. Nesse sentido, a atuação no GEEMPA se situa como mais um importante espaço 
de reflexão sobre práticas educativas e a relação antropologia e educação. No decorrer das atuações, foi possível sistematizar dados que levaram a retomar a temática da subjetividade, agora situada em outras referências, como parte dos dilemas relacionados ao exercício do magistério, envolvendo enorme complexidade de referências das educadoras, como pertencimentos étnicos e religiosos, questões de classe, gênero e outros. Os cursos do GEEMPA, e também do $\mathrm{GDE}^{66}$, situaram-se como espaço de articulação de muitos antropólogos pesquisadores do NIGS, em espaços de formação e também na troca de informações sobre aulas e turmas, o que ampliou a reflexão sobre a nossa prática que foi também incorporada à produção científica ${ }^{67}$.

Assim, o ensino de antropologia vem se situando na minha trajetória acadêmica, sempre mais, como uma prática reflexiva. Essas experiências fizeram e continuam fazendo parte das interlocuções em disciplinas que ministro na graduação e na pós-graduação (informações completas em anexo). Gostaria de destacar, dessa experiência, aprendizados sobre como ensinar antropologia, minha tentativa recorrente do exercício de uma prática dialógica, tanto nas disciplinas que ministro no curso de Ciências Sociais como em outros cursos nos quais o Departamento de Antropologia atua na UFRN.

Na graduação, tenho ministrado para o curso de Ciências Sociais disciplinas de Introdução à Antropologia, teoria e gênero ${ }^{68}$. Nos últimos anos, também fui responsável por várias turmas no oferecimento do componente curricular Pluralidade Cultural e Educação para a licenciatura em Ciências Sociais, um curso que tem permitido construir algumas relações importantes com as temáticas da diversidade nos contextos educacionais, bem como a reflexão sobre o modo como a diferença vem sendo alvo de avanços e recuos na formulação de políticas para a educação.

Na pós-graduação, ministrei cursos de gênero e também de teoria. Com a criação doutorado, em 2015, temos ampliado o leque de oferta de disciplinas e ministrar cursos na pós-graduação sempre se situa como um rico aprendizado e possibilidade de aprofundamento de referências teóricas e metodológicas.

\section{ATUAÇÃO INSTITUCIONAL, INTERINSTITUCIONAL E ADMINISTRAÇÃO}

Entre os desafios com que me deparei a partir do momento em que ingressei na UFRN, assumir atividades administrativas teve papel de destaque. Assim que ingressei, fui convidada a coordenar a chamada "Equipe de Antropologia", então ainda dentro do Departamento de Ciências Sociais. Tarefa difícil, mas sempre compartilhada com o grupo que, como já mencionei, empenhou-se na construção de um projeto para a área de Antropologia na UFRN.

Em 2001, coordenei o curso de Especialização em Antropologia. Com base nessa experiência, compartilhei com colegas o processo de elaboração do Programa de Pós-Graduação em Antropologia Social, que teve início em 2004, tendo assumido a coordenação no período de 2005-2007. Também participei ativamente dos colegiados de curso de graduação em Ciências Sociais, inclusive em processos de reformulação curricular, o que resultou em aprendizados importantes. Atualmente, sou vice-coordenadora do curso de Ciências Sociais Licenciatura e, junto com Irene Paiva na Coordenação, estamos em processo de construção da proposta de mais uma reformulação do projeto político-pedagógico e da grade curricular. 
No período de 2008-2009, realizei um estágio pós-doutoral e, no retorno, assumi a chefia do Departamento de Antropologia, de 2010 -2012. Em 2013, retornei à coordenação do PPGAS. No período de 2013 a 2015, coordenei também a elaboração do projeto de doutorado. As atividades assumidas no âmbito do PPGAS sempre se desenvolveram com forte diálogo com a antropologia brasileira, principalmente por meio da Associação Brasileira de Antropologia. Em 2001, recebemos o então presidente, Prof. Ruben Oliven, que participou da II Semana de Antropologia e destacou o em andamento curso de especialização. Em 2004, passei a integrar a diretoria da RBA, na condição de Diretora Regional. Em abril de 2005, junto com a aula inaugural do PPGAS, ministrada pelo então vice-presidente da ABA, Prof. Peter Fry, celebramos, também com a participação da Presidenta, Profa. Miriam Grossi, os 50 anos da ABA.

Mas foi na gestão 2013-2015, na Coordenação do PPGAS, que assumi, junto com os colegas do PPGAS, um dos maiores desafios, a saber: a participação na organização da $29^{\mathrm{a}}$ RBA, que foi realizada em Natal, na UFRN, na qual atuei como coordenadora da comissão local. Esse foi, sem dúvida, um dos períodos mais marcantes de diálogo com a antropologia e antropólogos brasileiros (e de outros países), repleto de aprendizados e que fez perceber a importância da cooperação para o êxito de atividades acadêmicas. Para tanto, contamos com a participação efetiva do Departamento de Antropologia e do PPGAS. Nessa direção, docentes e discentes mobilizaram diferentes setores da UFRN, de outras instituições e da cidade de Natal, o que fez com que a 29a RBA se tornasse um marco importante na sequência de reuniões da ABA. Nesse sentido, sou grata à Profa. Carmen Rial e à diretoria do biênio 2012-2014 pela confiança nessa importante tarefa. Na reunião realizada em Natal, fui eleita para o Conselho Científico da ABA, no qual continuo participando até o momento.

O êxito na realização da $29^{\mathrm{a}} \mathrm{RBA}$ está relacionado a uma prática de eventos que eu e meus colegas do DAN desenvolvemos. Desde 2000, acontece anualmente a Semana de Antropologia, sempre com temas específicos, o que tem suscitado a participação de todos os docentes na organização. A Semana se constituiu, ao longo desses anos, como um importante espaço de interlocução com os antropólogos e a antropologia produzida em diferentes instituições brasileiras. Além da Semana, também organizamos continuamente eventos no grupo de pesquisa GCS. Ainda no âmbito das atividades institucionais, a participação, como representante do CCHLA, na Comissão de Pesquisa-PROPESQ, no período de 2010-2012, permitiu ampliar o conhecimento sobre a UFRN. Ademais, nas duas ocasiões em que estive na Coordenação de Curso de Pós-Graduação em Antropologia, bem como na Chefia de Departamento no DAN, participei regularmente do CONSEC, oportunidade de diálogo com o corpo docente do CCHLA. E a participação em bancas de concurso para ingresso no Departamento de Antropologia.

Ainda como parte de diálogos e intercâmbios, destaco minha a participação em diferentes comissões, tais como o prêmio Lévi Strauss modalidade paper, durante a $28^{\mathrm{a}}$ Reunião de Antropologia em São Paulo, onde presidi a comissão julgadora; como membro do grupo que julgou o Premio Igualdade de Gênero, iniciativa do MEC/SECADI, na edição de 2012; como Presidente da Comissão Julgadora do Prêmio Capes de Teses, área de Antropologia, edição de 2016. Todos importantes espaços de interlocução importantes com a produção de conhecimento na antropologia brasileira.

Como parte das atividades interinstitucionais, conforme mencionei, mantive constantemente o diálogo com o NIGS/UFSC e também com o NAU/ USP, espaços de formação, respectivamente, do mestrado e do doutorado. No NIGS, desenvolvi uma trajetória que envolveu um amplo espectro de projetos, 
que articulam os principais eixos de minhas atividades de pesquisa, ensino e extensão, de modo particular na reflexão sobre gênero e subjetividade. Foi também no NIGS que desenvolvi aprendizados de pesquisas e práticas educativas em projetos coletivos, que associam a atividade acadêmica ao constante posicionamento político. No âmbito da pesquisa, uma experiência marcante foi a participação na equipe que realizou etnografias em Conferências Nacionais de Políticas para Mulheres, em âmbito Municipal, Estadual e Federal, no ano de 2011. O projeto, com o objetivo de realizar uma avaliação dos Planos Nacionais de Políticas para as Mulheres, envolveu também a realização de entrevistas com gestoras e gestores de diferentes ministérios, um importante aprendizado sobre os processos complexos da efetivação de políticas públicas.

Nas práticas educativas, pelo NIGS, a participação no GEEMPA e as articulações em torno do GDE. No período de 2010 a 2014, esse intercâmbio foi formalizado no âmbito do PROCAD, projeto financiado pela CAPES, no qual atuei como coordenadora geral, que envolveu, além de programas em Antropologia da UFRN e UFSC, também a UFAM. Esse projeto permitiu a realização de estágios sanduíches discentes, missões de pesquisa docentes, eventos, organização de grupos de trabalho em congressos, bem como o fortalecimento no sentido de participar da discussão de políticas públicas, sobretudo no que se refere a gênero e a práticas educativas.

Ainda em relação à criação de redes de pesquisa, o projeto PROCAD permitiu o envolvimento, meu e de outros docentes, em redes de maior amplitude, tais como o LIESS $^{69}$. Por meio de jornadas acadêmicas do PROCAD, estabeleci contato com essa rede de pesquisadores, o que tem ampliado as possibilidades de pesquisa e também de reflexão sobre a implementação de políticas públicas, por exemplo, na área de gênero e de práticas educativas, em diferentes países: Brasil, Espanha, Uruguai, Argentina, entre outros. No processo de construção dessa Rede, o grupo envolvido investiu na construção de intercâmbios, não só nos congressos do LIESS, mas também nas oportunidades de encontro proporcionadas em eventos de área, por meio de pré e pós-eventos. Entre as jornadas: pré-evento no Fazendo Gênero, em Florianópolis, 2013; Pós-Evento na 29a. RBA, em Pipa-RN, em 2014; Pré-Evento na RAM, Montevidéu, 2015. E ainda, como proposta de continuidade da construção de redes, no mês de agosto de 2017 contaremos com a presença, como Professor Visitante, do Coordenador da Rede LIESS, Prof. José Maria Valcuende Del Rio, da Unviersidad Pablo de Olavide, em Sevilha/Espanha, que estará em Natal para várias atividades acadêmicas.

Atualmente, sou Tutora do PET Conexões de Saberes, que assumi em fevereiro de 2015, dando continuidade a minha atuação em políticas de permanência, em se tratando de estudantes de origem popular que ingressam na universidade. Esse Programa resulta de uma continuidade em relação ao programa Conexão de saberes, no qual atuei de 2006 a 2008 e de 2009 a 2011. Trata-se de um espaço importante para continuidade das atividades de extensão, com atuação em diferentes espaços, por meio da orientação de 12 alunos de distintos cursos de graduação.

\section{FINALIZANDO: NA PERSPECTIVA DE CONTINUIDADES E DE NOVAS FRONTEIRAS}

Finalizo esta narrativa de eventos importantes da minha trajetória com o mesmo tom que iniciei: o prazer de "ler" esse processo e a percepção 
das possibilidades de continuidade na minha atuação profissional. Desde 2016, estou construindo um projeto de que amplia as investigações sobre antropologia, gênero e práticas educativas. Vivemos tempos difíceis e esse projeto até o momento não foi viabilizado em razão da não aprovação do pleito de financiamento.

Continuo integrando minhas atividades de ensino, pesquisa e extensão. Pretendo investir de modo mais sistemático em cursos e tópicos especiais, como forma de aprofundar aspectos específicos do campo de estudos de gênero e mobilizar uma também ampla bibliografia que vem se multiplicando constantemente. Conforme já mencionei, também estou finalizando um livro sobre o assentamento, que é o objeto de meus investimentos em pesquisa desde o mestrado. O livro chama-se Fronteiras Conquistadas e, numa narrativa do processo do grupo a partir de diferentes temporalidades, situa-se como um retorno e um agradecimento meu ao rico aprendizado antropológico que o contato com esse grupo proporcionou.

Também estamos iniciando mais um projeto de Educação a Distância no GCS. De modo diferente do projeto anterior, nesse, a equipe do GCS estará responsável pela redação do material a ser disponibilizado no Ambiente Virtual de Aprendizagem Moodle. Isso fez com que iniciássemos uma significativa mobilização dos estudantes de graduação, pós-graduação e docentes, em mais um empreendimento que valoriza a construção coletiva. Esse curso está relacionado a outras ações dentro do projeto, com o propósito de "Semear Gênero na Educação", como o diálogo com grupos PIBID e também com um centro de referência em saúde. Estou incluindo esse projeto nas minhas palavras finais em razão de simbolizar um dos maiores aprendizados que tive na minha trajetória acadêmica e que merece ser retomado nesses tempos sombrios: a importância da prática coletiva da pesquisa e a valorização de ações construídas em conjunto na educação.

Ações coletivas continuam sendo o único caminho para efetivamente enfrentar contextos de desigualdade. Muito obrigada a todos os colegas, estudantes, interlocutores na sala de aula, em projetos de extensão e pesquisa, mencionados direta e indiretamente, que se engajaram e continuam dispostos a continuar nesse projeto - antropológico — de construção da igualdade com respeito à diferença.

\section{NOTAS}

${ }^{1}$ De modo particular na forma como essa reflexão é realizada na Reprodução. Bourdieu (2009).

${ }^{2}$ A noção de fronteira agrícola está associada ao complexo processo de colonização dessa região, com a comercialização das terras. O Oeste catarinense foi o destino de muitos filhos de agricultores vindos do RS, principalmente entre 1950-1970. Referências para essa discussão: Renk (1990).

${ }^{3}$ Algumas companhias: Sul Brasil, Bertaso e Maia. Sobrenomes como Bertaso permanecem nomeando ruas nas cidades do Oeste catarinense, com destaque para o papel que tiveram na "colonização".

$234{ }^{4}$ Sobre as companhias colonizadoras no Oeste catarinense, ver Arlene Renk (1990).

${ }^{5}$ Um dos sentidos principais do investimento na colonização era a expectativa do que se considerava "limpeza" da área, por meio da implantação de um modo de exploração do solo, a produção agrícola e exploração intensiva, tal como apontado por Arlene Renk (1990) em estudo sobre os caboclos na "luta da erva". Os colonos alemães e italianos eram vistos como possuidores das características para implementação desse projeto.

${ }^{6}$ Essa referência do "urbano" sempre se situou para mim de maneira instigante. Nesse 
período, o urbano estava relacionado à energia elétrica, à TV, à comunicação por telefone e ao acesso ao consumo de produtos industrializados. O que se chamava "cidade" diferenciava-se pela presença desses equipamentos. Nessas pequenas cidades, assim como nas localidades rurais, predominava o modelo de relações da comunidade.

${ }^{7}$ A bibliografia sobre a Teologia da Libertação abrange uma lista imensa. Na época as principais referências eram os escritos de Leonardo Boff, Gustavo Gutierrez, entre outros, conforme revisão que fiz na minha dissertação de mestrado (SCHWADE, 1993).

${ }^{8}$ Projeto de dissertação do meu orientando de mestrado, José Ricardo Marques Braga, PPGAS/UFRN, em desenvolvimento e qualificado recentemente, com dados relevantes sobre esse processo de acesso e permanência.

${ }^{9} \mathrm{O}$ argumento de inclusão foi utilizado pela UFRN entre 2006-2012, em período anterior à legislação que prevê cotas. Tratava-se de uma pontuação específica para estudantes oriundos de escolas públicas.

${ }^{10} \mathrm{Na}$ UFRN, dividimos a atuação em grupos que atuavam em comunidades rurais e urbanas. Muitas ações envolviam cursinhos para preparação de estudantes do ensino médio para processos seletivos dos Institutos Federais de Educação e da UFRN.

${ }^{11}$ Participei como entrevistadora de um projeto coordenado pela Profa. Maria Ignes Paulilo. Realizamos entrevistas com residentes no Assentamento Putinga, Município de Matos Costa - SC.

${ }^{12}$ Naquele período, estavam sendo realizados os primeiros estudos sobre a proposta de organização dos assentamentos, com ênfase especial na cooperação agrícola, no trabalho coletivo e na organização desses territórios por meio da interlocução com o MST.

${ }^{13}$ GROSSI, Miriam P. (Org.). Trabalho de Campo e Subjetividade. Estamos reeditando essa coletânea, dentro do livro "Trabalho de campo, ética e subjetividade", a ser lançado em agosto de 2017.

${ }^{14}$ Ressalte-se que, nesse caso, a Cooperativa ordena não só a produção, mas ainda os direcionamentos políticos. Retomarei essa questão mais adiante.

${ }^{15} \mathrm{Um}$ relato organizado de minha trajetória durante essa pesquisa no assentamento Conquista na Fronteira, que se estendeu até períodos recentes, encontra-se publicado em Schwade (2013).

${ }^{16}$ Essa primeira etapa foi desenvolvida com a presença de um colega que então fazia a sua pesquisa para o mestrado em Sociologia, John Kleba.

${ }^{17}$ Argumentei que, como o assentamento passava por um momento ainda de organização, ficar em uma única casa facilitaria minha participação com alguns itens alimentícios, o que foi aceito. No início da segunda etapa, tive a companhia de Alícia Gonçales.

${ }^{18}$ Conforme mencionei acima, antes da primeira etapa de pesquisa eu construí um processo de aproximação, a partir do contato com militantes que atuavam na região. Como eu também estava envolvida com grupos de militância na igreja católica, tal pertencimento facilitou o diálogo, desde que tínhamos referências comuns.

${ }^{19}$ O Núcleo de Identidade de Gênero e Subjetividade (NIGS) UFSC, coordenado pela Profa. Miriam Grossi e do qual faço parte desde a fundação, nasceu de um processo de reflexão sobre subjetividade na pesquisa de campo, em um evento de Antropologia ABINHA, em Curitiba, em 1991.

${ }^{20}$ Reunião de Antropologia do Mercosul, em 2003, Florianópolis, Coordenação do GT Antropologia, trabalho de campo e subjetividade, com Vagner Gonçalves da Silva.

${ }^{21}$ Reunião Brasileira de Antropologia - RBA: em 2004, Recife, Coordenação do GT Antropologia, trabalho de campo e subjetividade, com Vagner Gonçalves da Silva; Em 2006, Goiânia, Coordenação do GT Feminismo, relações de gênero e subjetividade, com Maria Lago; Em 2008, Porto Seguro, Coordenação do GT Antropologia, relações de gênero e subjetividade, com Maria Lago; Em 2012, PUC/SP, Coordenação do GT Gênero, deslocamentos, militância e democracia.

${ }^{22}$ Associação Nacional de Pós-Graduação e Pesquisa em Ciências Sociais-Coordenação do GT Gênero, militâncias, deslocamento e democracia, com Miriam Grossi, 2011 e 2012.

${ }^{23} \mathrm{Em} 2006$, na 25 $\mathrm{RBA}$, essas atividades de GTs foram direcionadas para um recorte mais específico, agora em parcerias mais diretas com o NIGS e com a participação da Profa. Mara Lago, sublinhando a dimensão de gênero, o que repetimos na $26^{\mathrm{a}}$ e na $28^{\mathrm{a}}$ RBA, respectivamente, em Porto Seguro e São Paulo. O tema da subjetividade também 
foi destaque em duas edições de GTs na ANPOCS, em 2011 e em 2012, em parceria com Miriam Grossi e Aline Bonetti.

${ }^{24}$ Livro organizado por Cristina Patriota de Moura e Lisabete Coradini (2015), texto "Etnografia e subjetividade na pesquisa antropológica" (SCHWADE, 2016).

${ }^{25}$ A "mística" nas atividades do MST se constitui em ações que objetivam o reforço contínuo da luta enaltecendo seus propósitos, por meio da utilização de elementos da linguagem teatral tendo Augusto Boal como referência principal. Essa prática foi se consolidando no decorrer do processo de organização do MST mas, já durante a realização da pesquisa em 1990 e 1991, em vários momentos, ouvi sobre a "necessidade de criar uma mística forte", em contextos de comparações e definições, nos quais se evidenciava o modelo de militância reconhecido para a luta.

${ }^{26}$ Conforme menciono adiante, retornei ao assentamento em 2011 para nova etapa de pesquisa e então ficou ainda mais evidente o componente religioso da luta política, na fala de uma das minhas principais interlocutoras.

${ }^{27}$ Estou finalizando um livro sobre o assentamento, chamado "Fronteiras Conquistadas", que retoma esse processo de pesquisa acrescido de novas etapas que relato na sequência. Entre 2010-2013, desenvolvi um projeto de pesquisa com o título "Local, Global, Diálogos e trânsitos: gênero e assentamentos rurais em contextos de globalização cultural" sobre trajetórias militantes, de modo especial, de mulheres. Artigos relacionados a essa temática são: SCHWADE (2014); SCHWADE (2017).

${ }^{28}$ Lemos, nesse curso, textos do livro Writing Culture (MARCUS; CLIFFORD, 1986), discutimos também as primeiras reações a essas reflexões, inclusive no Brasil, com Tereza Caldeira (1989), Vilson Trajano (1986), entre outros autores.

29 "Sociedades Complexas", tal como essa discussão aparece na obra de Gilberto Velho (1981).

${ }^{30}$ Ministrei também outros cursos, mas fui contratada para ocupar a vaga da Profa. Arlene Renk, referência importante na Antropologia naquela instituição, afastada para doutorado.

${ }^{31}$ Programa de Pós-Graduação em Antropologia Social

${ }^{32}$ Universidade do Oeste de Santa Catarina.

${ }^{33}$ SCHWADE (2006). BIB-Boletim Informativo e Bibliográfico.

${ }^{34}$ Feminino situado como parte de um tripé, junto com ecologia e espiritualidade, compunha o eixo central das práticas chamadas neoesotéricas ou nova era, conforme MAGNANI (1998).

${ }^{35}$ Localizo o rendimento dessa categoria, desenvolvida por MAGNANI (2012, entre outros), no estudo de conexões estabelecidas entre diferentes, de acordo com a sua apropriação.

${ }^{36}$ SCHWADE (2010) "Carnaval da Nova Consciência".

${ }^{37}$ Pró-Reitoria de Pesquisa.

${ }^{38}$ Esse curso faz parte do Programa Nacional de Educação e Reforma Agrária-RONERA, desenvolvido por meio do convênio com o Instituto Nacional de Colonização e Reforma Agrária-INCRA/MST e UFRN. Retomo adiante.

${ }^{39}$ Esse curso adota a pedagogia da alternância, com tempo escola e tempo comunidade.

${ }^{40}$ A "ciranda" é uma prática comum nas atividades do MST. Trata-se da disponibilização de espaços e pessoal para realizar atividades educativas com as crianças que acompanham mães nas atividades de formação e eventos.

${ }^{41}$ Trata-se de um espaço de formação do MST, instalado em uma antiga escola agrícola.

${ }^{42}$ Lerrer (2008) faz uma interessante abordagem desses processos migratórios e seus significados.

${ }^{43}$ A referência para a discussão da comparação inerente ao exercício antropológico como elucidação mutua é GEERTZ (1978).

${ }^{44}$ Nessa ocasião, eu estava no Oeste Catarinense, na casa de meus familiares e meu pai me acompanhou na ida ao assentamento.

${ }^{45}$ Sobre as relações de trabalho, a leitura de etnografias que versavam sobre contextos transnacionais foram oportunidade de um olhar distanciado sobre a desigualdade que vivemos na sociedade brasileira. Lembro, particularmente, da etnografia realizada por Nicole Constable, sobre mulheres Filipinas que se deslocam para trabalhar como em- 
pregadas domésticas em Hong Kong, sobre a qual fiz uma resenha que foi publicada na revista "Horizontes Antropológicos" (SCHWADE, 2009).

${ }^{46}$ Movimento de Mulheres Camponesas.

${ }^{47}$ Movimento de Mulheres Trabalhadoras Rurais.

${ }^{48} \mathrm{Um}$ texto que sempre se situou como referência para minhas reflexões é o trabalho de Milie Thayer (2004).

${ }^{49}$ Secretaria Especial de Políticas para as Mulheres

${ }^{50}$ Pedro Magrini e Giona Licia, da UFSC, respectivamente, estudantes do doutorado interdisciplinar em ciências sociais e do curso de graduação em ciências sociais.

${ }^{51}$ SCHWADE (2014) e SCHWADE E PAIVA (2014), textos em que desenvolvi reflexões sobre trajetórias militantes.

${ }^{52}$ Reflexões a esse respeito em SCHWADE E COSTA (2012) e SCHWADE E PAIVA (2014).

${ }^{53}$ Idem.

${ }^{54}$ As reflexões que seguem fazem parte de um artigo que se encontra no prelo, com o título "Gênero e Assentamentos Rurais em contextos de Globalização Cultural", a ser publicado em coletânea organizada por Carlos Guilherme O. do Vale e Luiz Fernando Dias Duarte, pela Editora Annablume, no segundo semestre de 2017.

${ }^{55}$ Nesse sentido, é interessante a discussão de Garcia (1997) sobre a militância nos anos de chumbo no Brasil e na Argentina. O autor argumenta uma espécie de "armadilha" no resgate da história da participação feminina, salientando a necessidade de considerar, não uma "história paralela", mas os conflitos e as tensões relacionados à atuação política tendo em vista os papéis de gênero.

${ }^{56}$ Nesse sentido, conforme pontua Teles (2010, p. 163), repete-se uma situação frequente nos chamados espaços populares, qual seja a referência ao feminismo como exclusão dos homens, enquanto gênero incluiria os homens.

${ }^{57}$ No contexto da reflexão sobre a prática, como diz a autora, "history makes people, but people makes history" (ORTNER, 2006).

${ }^{58} \mathrm{Nas}$ palavras do autor, “...the concept of the cultural allows one to approach or assess the object of analysis better and in a more adequate way than the idea of culture, because culture somehow requires that everything else is subsumed under it" (RABINOW; MARCUS, 2008, p. 110).

${ }^{59}$ Projeto aprovado com financiamento no edital universal do CNPq 2012.

${ }^{60}$ Ver o dossiê organizado por SCHWADE, E.; WOORTMANN, Ellen. Revista Vivência de Antropologia, n. 43, 2014. Ver ainda as coletâneas de Scott e Cordeiro (2010a, 2010b).

${ }^{61}$ Como primeiros resultado dessa pesquisa, um capítulo de livro a ser publicado em 2017 (SCHWADE, 2017). O aluno José Maycon da Silva, que foi bolsista PIBIC nessa pesquisa, elaborou monografia de conclusão de curso de graduação em Ciências Sociais, sobre juventude, defendida em 2017.

${ }^{62}$ Esse projeto foi aprovado no âmbito da PROPESQ/UFRN e desde 2016 conta com a participação de uma estudante de Iniciação Científica, bolsa PIBIC. No entanto ainda não tem financiamento externo - foi aprovado por mérito no edital universal do CNPq de 2016 mas, em razão do difícil momento em que vivemos no que se refere ao investimento de fomento para pesquisas, não foi contemplado com financiamento,

${ }^{63}$ Lista das dissertações, teses e monografias em anexo. Conforme mencionei, estive vinculada ao programa de Pós-Graduação em Ciências Sociais da UFRN entre 20022010, o que me fez ter orientações de doutorado concluídas antes do início do curso de doutorado no PPGAS.

${ }^{64} \mathrm{Um}$ relato da experiência do curso de especialização encontra-se no livro que resultou de um importante encontro de discussão sobre Ensino de Antropologia no Brasil, realizado em 2002, em Florianópolis. SCHWADE, 2004.

${ }^{65}$ Grupo de Estudos sobre Educação, Metodologia da Pesquisa e Ação, coordenado pela Professora Esther Grossi.

${ }^{66}$ Gênero e Diversidade na Escola.

${ }^{67}$ Como publicações importantes: um artigo em parceria com a minha colega de departamento, Rozeli Porto, publicado na Revista “Anthropológicas” (SCHWAD; PORTO, 
2016); encontra-se em processo de finalização um livro que foi resultado das trocas acadêmicas das atividades PROCAD, com lançamento previsto para o segundo semestre de 2017.

${ }^{68}$ Lista complexa das disciplinas ministradas na graduação e pós-graduação no anexo I.

${ }^{69}$ Laboratório Iberoamericano para el estudio sociohistorico de las sexualidades. Trata-se de uma rede com a qual venho construindo diálogos, junto com outras pesquisadoras do NIGS, desde 2013. Em 2016 participei do Congresso bianual em Granada, na Espanha.

\section{REFERÊNCIAS}

BOURDIEU, Pierre. A reprodução. Petrópolis: Vozes, 2009.

CALDEIRA, Tereza. A presença do autor e a pós-modernidade em antropologia. Revista Novos Estudos CEBRAP, v. 2, 1989.

CARVALHO, José Jorge. Entrevista. Cadernos de Campo. São Paulo, Entrevistadores Ari Lima e Pedro Jaime, n. 19, p. 207-227, 2010.

CASTRO, Elisa Guaraná. Juventude rural: "apenas uma palavra” ou "mais que uma palavra". Trabalho apresentado no 29 Encontro da ANPOCS, Caxambu, 2005.

CHAVES, Cristine. A marcha dos Sem-Terra. In: Peirano, Mariza (org.). O dito e o feito: ensaios de antropologia dos rituais. Rio de Janeiro: Relume Dumará, 2002.

. Os limites do consentido. In: Fonseca, Claudia e Brites, Jurema. Etno$\overline{\text { grafias }}$ da participação. Santa Cruz do Sul: UNISC, 2006.

COMEFORD, John. Reuniões camponesas. In: Peirano, Mariza (org.). O dito e o feito: ensaios de antropologia dos rituais. Rio de Janeiro: Relume Dumará, 2002.

FONSECA, Claudia. Quando cada caso não é um caso. Revista Brasileira da Educação, Caxambu, n. 10, set. 1998.

GARCIA, Marco Aurélio. O Gênero da Militância: notas sobre as possibilidades de uma outra história na ação política. Cadernos Pagu, n. 08, Campinas, 1997.

GROSSI, Miriam. Na busca do outro encontra-se a si mesmo. Trabalho de Campo e Subjetividade. NIGS: UFSC, 1992.

GROSSI, Miriam. Jeito de freira. Estudo Antropológico sobre vocação religiosa feminina. Cadernos de Pesquisa. São Paulo: Fundação Carlos Chagas, 1990.

HANNERZ, Ulf. Fluxos, fronteiras, híbridos: palavras-chave da antropologia transnacional. Mana, Rio de Janeiro, v. 3, n. 1, 1997.

HANNERZ, Ulf. Being There... and There... and There! Reflections on Multi-Site Ethnography. In: Robben, Antonius C. G. Ethnographic Fieldwork: An Anthropological Reader. Blackwell Publishing, 2006.

LAMPHERE, Lousie; RAGONÉ, Helena; ZAVELLA, Patricia (org.). Introduction, 1997. In: Situated lives: gender and culture in everyday life. New York: Routledge.

LEITE, Sérgio L.; S. HEREDIA, B., MEDEIROS, L. et al, 2004. Impactos dos assentamentos: um estudo sobre o meio rural brasileiro. NEAD Estudos, Editora UNESP.

LERRER, Débora Franco. Trajetória de militantes sulistas: tradição e modernidade do MST. Tese (doutorado), Universidade Federal Rural do Rio de Janeiro, Instituto de Ciências Humanas e Sociais, 2008.

MAGNANI, José Guilherme. Mystica Urbe: um estudo antropológico sobre o circuito neo-esotérico na metrópole. São Paulo, Studio Nobel, 1999. 
. Da periferia ao Centro: trajetórias de pesquisa em antropologia urbana. São Paulo: Terceiro Nome, 2012.

MARCUS, George and Rabinow, Paul with Faubion, James and Rees, Tobias. Designs for an anthropology of the contemporary. Duke University Press. 2008. MARCUS, George. Ethnography in/of the world system: the emergence of multi-sited ethnography. Annual Review of Anthropology, 1995.

. Writing Culture: the poetics and the politcs of ethnography. University of Califórnia Press, 1986.

MARTINS, José de Souza. Expropriação e violência: a questão política no campo. Editora Hucitec, 1980, 181p.

. Sobre o modo capitalista de pensar. Editora Hucitec, 1982.

NOVAES, Regina. Juventude e Sociedade: jogos de espelhos. Sentimentos, percepções e demandas por direitos e políticas públicas. Disponível em: http:// www.antropologia.com.br/arti/colab/a38-rnovaes.pdf. Acesso em: 20 abr. 2010.

ORTIZ, Renato. A procura de uma sociologia da prática. In: Bourdieu. Coleção Grandes Cientistas Sociais. São Paulo: Ática, 1983.

ORTNER, Sherry B. Anthropology and social theory: culture, power and the acting subject. Durahm: Duke University Press, 2006.

ORTNER, Sherry. Entrevista com Sherry Ortner. Cadernos Pagu, Campinas, UNICAMP, n. 27, 2006.

ORTNER, Sherry. Subjetividade e crítica cultural. Horizontes Antropológicos, Porto Alegre, v. 13, n. 28, 2007.

ORTNER, Sherry. Entrevista. A máquina de cultura: de Geertz a Hollywood. Mana, Rio de Janeiro, PPGAS/Museu Nacional, v. 13, n. 2, 2007.

RENK, Arlene. A luta da Erva: um oficio étnico da nação brasileira no oeste catarinense. Dissertação de Mestrado, Rio de Janeiro: Museu Nacional, 1990.

ROBBEN, Antonius. Multi-Sited Fieldwork. In: Ethnographic Fieldwork: an Anthropological Reader. Wiley-Blackwell, 2006.

SCHWADE, Elisete. Poder do Sujeito, poder do objeto. Relato de uma experiência de pesquisa em um assentamento de trabalhadores rurais. In: Grossi, Miriam P. (org.). Trabalho de campo e subjetividade, NIGS/UFSC, 1992.

. A luta não faz parte da vida... é a vida. Dissertação de mestrado, PPGAS/ UFSC, 1993.

SCHWADE, Elisete. Ensino de Antropologia e Formação de Antropólogos: cursos de especialização e mestrado profissionalizantes. In: GROSSI, Miriam; TASSINARI, Antonella; RIAL, Carmem (org.). O Ensino de Antropologia no Brasil: formação, práticas disciplinares e além-fronteiras. Florianópolis: Nova Letra/ABA, 2006.

. Neo-esoterimo no Brasil: a construção de um campo de estudos. Revista Brasileira de Informação Bibliográfica em Ciências Sociais - bib, São Paulo, n. 61, 2006.

SCHWADE, Elisete; GROSSI, Miriam, P. (org.). Política e Cotidiano: estudos antropológicos sobre gênero, família e sexualidade. Florianopolis: Nova Letra/ ABA, 2006.

SCHWADE, Elisete; CONSTABLE, Nicole. Maid to order in Hong Kong: stories of migrant workers. Horizontes Antropológicos, Porto Alegre, v. $15 \mathrm{n}$. 32, jul./dez. 2009.

SCHWADE, Elisete; VALLE, Carlos Guilherme (org.). Processos Sociais, Cultura e Identidades. São Paulo: Annablume, 2010.

SCHWADE, Elisete. Gênero e juventude em assentamentos rurais. In: SCHWADE, Elisete; VALLE, Carlos Guilherme (org.). Processos Sociais, Cultura e Identidades. São Paulo: Annablume, 2010. 
. Carnaval da nova consciência. In: Religião e Sociedade, v. 31, n. 1, Rio de Janeiro, jun. 2011.

. Construção da militânica, gênero e geração no MST e em assentamentos rurais: reflexões sobre um processo de pesquisa. In: OLIVEIRA, Kelly Emanuelly; OLIVEIRA, Luciana Maria Ribeiro; NEVES, Ednalva Maciel. (org.). Pesquisa e ética na antropologia contemporânea: territorialidade, gênero, saúde e patrimônio. 1. ed. João Pessoa: Editora Universitária UFPB, v. 01, p. 41-80, 2013.

. Gênero e ativismo político: mulheres no MST e em assentamentos rurais. In: Gláucia de Oliveira Assis Luzinete Simões Minella Susana Bornéo Funck. (org.). Entre lugares e mobilidades: desafios feministas. 1. ed. Tubarão: Copiart, v. 03, p. 229-248, 2014.

. Etnografia e subjetividade na pesquisa antropológica. In: PATRIOTA, Cristina; CORADINI, Lisabete. Trajetórias antropológicas: encontros com Gilberto Velho. ABA/UFRN, 2016.

. Entre contextos rurais e urbanos: gênero, ação política e empoderamento de mulheres residentes em assentamentos rurais. In: ANDRADE, Darlane Silva Vieira; RODRIGUES, Cristiano Santos; MANO, Maíra Kubik; ZUCCO, Maise Caroline; ARAUJO, Janja (orgs.). Territorialidades: dimensões de gênero, desenvolvimento e empoderamento de mulheres. 1. ed. Coleção Bahianas. NEIM/UFBA Salvador: EDUFBA, 2016, v. 1, 2017, 200p.

SCHWADE, E.; COSTA, M. G. G. Discursos e feminismos em movimento entre a Marcha Mundial de Mulheres e o MST. Sociais e Humanas, v. 25 -2, p, 2012.

SCHWADE, Elisete; WOORTMANN, Ellen. Mulheres em Contextos Rurais. Vivência: Revista Vivência de Antropologia, v.1, n. 43, 2014.

SCHWADE, Elisete; PAIVA, Irene. A. Nas resistências: ação política, jovens e mulheres no MST e em assentamentos rurais. Vivência: Revista de Antropologia, v. 1, n. 43, 2014.

SCHWADE, Elisete; PEREIRA, Edmundo (org.). Entre interiores e capitais: antropologia, formação e pesquisa no Rio Grande do Norte. São Paulo: Annablume, 2015.

SCHWADE, Elisete; PORTO, Rozeli. O Ensino de Antropologia na Capacitação de Educadoras/es: Experiências Subjetivas em Processo. Revista Anthropológicas, Recife: UFPE, v. 27, n. 1, 2016.

SCHWADE, Elisete; RIAL, Carmen (orgs.). Diálogos antropológicos contemporâneos. Brasília: ABA Publicações, 2016.

SCOTT, Parry. Morais, religião e sexualidade em contextos urbano, rural e indígena: namoro, aborto e responsabilidade. In: SCOTT, Parry; ATHIAS, Renato; QUADROS, Marion T. (orgs.). Saúde, Sexualidade e familias urbanas, rurais e indígenas. Recife: editora UFPE, 2007.

SCOTT, Parry; Cordeiro, Rosineide; Menezes, Marilda (orgs.). Gênero e geração em contextos rurais. Florianópolis: Editora Mulheres, 2010.

STOLKE, Verena. La mujer es puero cuento: la cultura de genero. In: Revista de Estudos Feministas, Florianopolis, v. 12, n. 2, 2004.

THAYER, Millie. Feminismo transnacional: re-lendo Joan Scott no sertão. In: Revista Estudos Feministas, Florianópolis, v. 9, n. 1, 2001.

240 TELES, Maria Amélia de Almeida. Caminhos transversais dos feminismos e dos movimentos sociais. In: Rial, Carmen e Pedro, Joana. Diversidades: dimensões de gênero e sexualidades. Florianópolis: Editora Mulheres, 2010.

SIGAUD, Lígia; BENOIT, L'Estoile. Ocupações de terra e transformações sociais: uma experiência de etnografia coletiva. Rio de Janeiro: FGV, 2006.

TRAJANO, Wilson. Que barulho é esse, dos Pós-modernos? Anuário Antropológico. Brasília, UNB,1986. 
VELHO, Gilberto. Individualismo e Cultura. Rio de Janeiro: Zahar, 1981.

VELHO Gilberto. Subjetividade e sociedade: uma experiência de geração. Rio de Janeiro: Zahar, 1998. 